\title{
LA-5211-MS
}

$k \%<\leqslant 6$

INFORMAL REPORT

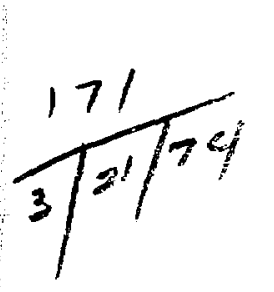

\section{Subterrene Electrical Heater Design and Morphology}


This report was prepared as an account of work sponsored by the United States Government. Neither the United States nor the United States Atomic Energy Commission, nor any of their employees, nor any of their contractors, subcontractors, or their employees, makes any varranty, express or im. plied, or assumes any legal liability or responsibility for the accuracy, completeness or usefulness of any information, apparatus, product or process disclosed, or represents that its use would not infringe privately owned rights.

In the interest of prompt distribution, this LAMS repart was not edited by the Technical Information staff.

Printed in the United States of Arnerica. Available from National Technical Information Service

U. S. Department of Commerce 5285 Port Royal Road

Springfield, Virginia 22151

Price: Printed Copy \$4.00; - Microfiche \$1.45 


\section{LA-5211-MS \\ Informal Report \\ UC-38}

ISSUED: February 1974

\title{
Subterrene Electrical Hecter Design and Morphology
}

\author{
by
}

P. E. Armstrong

Work supported in part by a grant from National Science Foundation, Research Applied to National Needs (RANN).

This report was prepared as on account of work
sponsored by the United States Government. Neither
the United States nor the United States Atomic Energy
Commission, nor any of their employees, nor any of
their contractost, subcontractors, or theis employees,
makes any warranty, express or implied, or assumes any
legul linbility or responsibility for the accuracy, com-
pleteness or usefulneis of any information, apparatus,
product or process disclosed, or represents that tts use
would not iniringe privately owned rights.


I. Introduction 1

II. Experimental Heaters and Prototype
Penetrators

A. Metallic Element Conduction lleat
Transfer Designs

1. Tungsten wire 2

2. Split Tungsten Rod 4

3. Flat Tungsten Ribion 5

B. Graphite Element Conduction Heat-Transfer
lleaters and Prototype Peretrators

1. Polycrystalline-Pyrolytic Graphite
Heater Stack

2. Penetrator Design witil Pyrolytic-Graphite

3. Direct Heating in Graphite Penetrator

4. Helical Polycrystalline Graphite Ribbon
lleater

5. Polycrystalline Graphite Rod Heaters 10

C. Graphite-Element, Radiation Heat-Transfer Heaters

1. Graphite Helix 11

2. Graphite Helix in a Heat-Pipe Penetrator 11

3. Pyrolytic-Graphite Stacked-Disk lleaters 13

$\begin{array}{ll}\text { a. Initial Development and Final } & 13 \\ \text { Configuration } & \end{array}$

b. Sealed unit for Field Use 14

c. Long Heater Elements 16

d. Larger-Diameter Penetrator Designs 17

e. Multiple Heater Stacks Electrically
Connected in Parallel

4. Annular Pyrolytic-Graphite Ring Heaters 18

$\begin{array}{ll}\text { a. Alluvium-Coring 57-mm-diam } & \\ \text { Penetrator } & 18\end{array}$

b. Basalt Extruding 57-mm-diam
Penetrator

C. Basalt-Stripping-Nozzle Extruding
Penetrator

$\begin{array}{ll}\text { d. Secondary-Heater Extruding } & \\ \text { Penetrator } & 20\end{array}$

Alluvium 114-mm-diam Coring
Penetrator

f. Summary of Experimental Heaters
and Prototype Penetrators 
III. Supporting studies and Experiments

to Develop Design Data

A. Materials Compatibility studies

B. Thermal Enissivity Studies

C. Thermionic Emission Studies

D. Studies of the Electrical Resistivity of Pyrolytic Graphite

IV. Design studies for Other Types of Electrical Heating

A. Electron Beam Internal Heating

B. Voltage-Current Conversion Schemes

v. Conclusion 


\title{
SUBTERRENE ELECTRICAL HEATER DESIGN AND MORPHOLOGY
}

\author{
by
}

\section{P. E. Armstrong}

\begin{abstract}
The design, construction, and testing of a variety of electrical neaters for small-diame'cer Subterrene penetrators has been pursued. The incompatibility of refractory materials at the required operating temperatures of $2000 \mathrm{~K}$ and the large heat-flux requirements posed the most difficult design problems. Heat fluxes of up to $2.0 \mathrm{MW} \mathrm{m}^{-2}$ were obtained from pyrolytic-graphite radiant heat-transfer elements and were as high as $2.5 \mathrm{MW} \mathrm{m}-2$ when this type of heater was combined with a lithium heat-pipe assembly. Penetrators using radiant heaters produced both vertical and horizontal holes of 50 num diameter up to lengths of $25 \mathrm{~m}$, whereas holes of up to $64 \mathrm{~mm}$ diameter and $0.5 \mathrm{~m}$ long were produced in basalt and other rock samples in the laboratory.
\end{abstract}

\section{INTRODUCTION}

A new excavating technology based on the concept of rock-melting is bejng developed at Los Alamos Scientific Laboratory. Ultimately, tunnels and deep holes will be formed through a variety of geological formations (including hard, dense rock and loosely consolidated materials) with a nuclear-powered, self-propelled device called Nuclear subterrene. ${ }^{1}$ Preliminary studies of the concepts involved are being conducted with devices that produce holes of relatively small diameter by using electric power.

Electric energy can be converted to the heat necessary for rock-melting by a variety of nethods, some of which are listed below in order of increasing complexity:

- Ohmic heating - an electric current produces heat as it passes through a heater element of finite resistance, the power dissipated in the element being simply the product of current squared and resistance.

- Induction heating - circulating rf electrical currents are induced in a finite-resistance element by electromagnetic coupling between the element and a low-resistance inductive circuit.

- Electron-beam heating - the energy of a stream of electrons accelerated in an electrical field is converted to heat at the anode.

- Gaseous discharge heating - gas discharges produced in a plasma arc, where the arc electric energy source is a high-temperature highly ionized gas, which in turn radiates thermal energy to the surroundings.

- Laser heating - electric energy is first converted into a highly concentrated beam of electromagnetic radiation in the visible light-frequency range which is then absorbed by the sock.

Ohmic heating, because of its simplicity and convenience in producing the desired temperatures, was used in all the penetrator studies to date. 
A variety of these ohmic electrically heated prototype penetrators have been designed ${ }^{2,3}$ and tested. Laboratory and fieldtest data 4,5 have demonstrated the feasibility of the basic concepts and have indicated a wide range of potential applications. ${ }^{6}$

The formation of the debris as a liquid rock melt has verified the potential contribution of this technique to new solutions of the three major problem areas of the excavation process :

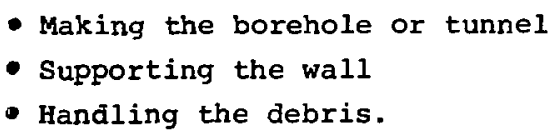

Design and development of electric heaters is a very important part of the development program. The various configurations that have been considered $w j .11$ be reviewed in this report and the characteristics of the heaters that have been fabricated and tested will be described.

The basic problem was one of materials compatability at the required operating temperatures. Practical considerations limited the choice of heater-body materials to those that could be readily fabricated. The required penetrator-body surface temperature of $~ 1800 \mathrm{~K}\left(2700^{\circ} \mathrm{F}\right)$ eliminated most of the common heating-eloment alloys from consideration, and anticipated fabrication difficulties with brittle refractory conductors (e.g., carbides and nitrides) eliminated these promising materials from the initial testing program.

The major design problem resulted from the requirement for large heat fluxes from the heater surfaces. These high fluxes are necessary to provide the high heat flow from the penetrator to the rock that is required to melt the rock at useful rates. Thermal resistances of electrical insulators had to be kept low to reduce internal temperature gradients. 7 Large gradients would require increased heater temperatures, which in turn, would greatly accelerate the chemical reaction between heater surfaces and adjacent materials.
The heat fluxes were very much larger than those provided in commercially available high-temperature furnaces, and this technology therefore was not airectly applicable to the solution of the heater problem. The design approach was rather to combine existing heat-transfer data with thermodynamic data and experimental reaction-rate data $^{8}$ to predict heater performance, and then to evaluate short-term test results on the basis of the predicted behavior.

Because time and resources were limited, heater development was mainly accomplished in direct conjunction with the design and testing of complete penetrator bodies and stems. This approach, however, produced incomplete data on operating lifetimes and maximum heat fluxes for some types of heaters. Reliability considerations, and ease and speed of fabrication, has led therefore to the almost exclusive use of resistanceheated, pyrolytic-graphite, radiation heaters in recent designs. While this type of heater performs very well, other electric heater types may offer particular advantages for specific applications in the future.

11. EXPERIMENTAI HEATERS AND PROTOTYPE PENETRATORS

A. Metallic El sment Conduction Heat-

1. Tungsten wire

Tungsten wire was used as a heating element in several early penetrator designs, as shown in Figs. 1 and 2. Wire elements have great mechanical strength and can be built to produce a range of electrical resistances by simply varying the length and diameter of the wire. Tungsten was chosen because of its high melting point ( $3600 \mathrm{~K}$ ) and relative chemical stability. The design of the 50-mm-diam penetratoi shown in Fig. 2 called for a 3-kw power source operating at $-30 \mathrm{~V}$ and $100 \mathrm{~A}$, with a resistance at operating temperature of $0.3 \Omega$. The dianeter of the wire was $0.38 \mathrm{~mm}$ and three. parallel windings were employed, using a triple lead-threaded boron-nitride (BN) coil 
TABLE I

SUMMARY OF PARAMETERS FOR EARLY PROTOTYPE PENETRATOR TEST RESULTS - MODEL 50-1 CONE WITH WIRE ON BN CONE

A. Maximum Penetration-Rate Conditions

Maximum penetration rate

$0.04 \mathrm{~mm} \mathrm{~s}^{-1}(12 \mathrm{ft} / \mathrm{day})$

Thrust level

Total electrical power

$3600 \mathrm{~N}(800 \mathrm{1b})$

Heat to $\mathrm{H}_{2} \mathrm{O}$ coolant

$2.2 \mathrm{~kW}$

Average wire temperature

$1.0 \mathrm{~kW}$

$\sim 1700 \mathrm{k}$

Penetrator surface temperature (hottest point)

$\sim 1650 \mathrm{~K}$

Average heat flux to rock

$\sim 0.2 \mathrm{MW} \mathrm{m}^{-2}$

B. Maximum Depth of Penetration Conditions ${ }^{a}$

Maximum depth of penetration

Penetration rate

Thrust levels

$102 \mathrm{~mm}(4.0 \mathrm{in.})$

$0.0^{\mathrm{a}}$

9000 to 22000 N $(2000$

to $4800 \mathrm{lb}$ )

Total electrical power

$2.0 \mathrm{~kW}$

Heat to $\mathrm{H}_{2} \mathrm{O}$ coolant

$1.1 \mathrm{~kW}$

Average wire temperature

$\sim 1700 \mathrm{~K}$

$a_{\text {At }}$ time when conical portion hung up on the rock

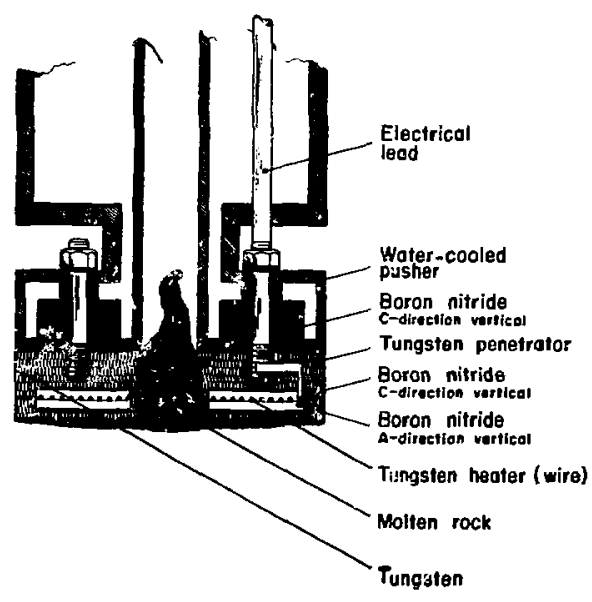

Fig. 1. Extrusion penetrator with tungsten wire heater.

form. Because tungsten has a large positive temperature coefficient of resistivity (Fig. 3) an average wire temperature can be calculated from voltage and current measurements. This heater was held at an average wire temperature of $\sim 1670 \mathrm{~K}$ for $\sim 3.5 \mathrm{~h}$ before failure. The test was terminated after a short circuit developed between the wire element and the molybdenum penetrator body. The conditions during the test are shown in Table I and Figs. 4 and 5. The indicated maximum average wire temperature was $1870 \mathrm{~K}$ althougn tine wire was locally probably considerably hotter. Failure occurred from a reaction between tungsten wire, BN insulator material, and molybdenum penesrator body. The boron nitride contained several percent of $\mathrm{B}_{2} \mathrm{O}_{3}$, which would have been a volatile liquid at $1870 \mathrm{~K}$.

While this type of heater probably would have shown greatly increased useful. life if constructed from purer $B N$, local overheating would remain a problem. At the overall indicated heat flux of $0.20 \mathrm{MW} / \mathrm{m}^{2}$ and witin a wire spacing of $\sim 3.4 \mathrm{~mm}$, a flux about nine times higher $\left(1.8 \mathrm{MN} / \mathrm{m}^{2}\right)$ was zequired at the surface of the wires. Small voids or gaps, created by the differences in thermal expansion of the tungsten, 


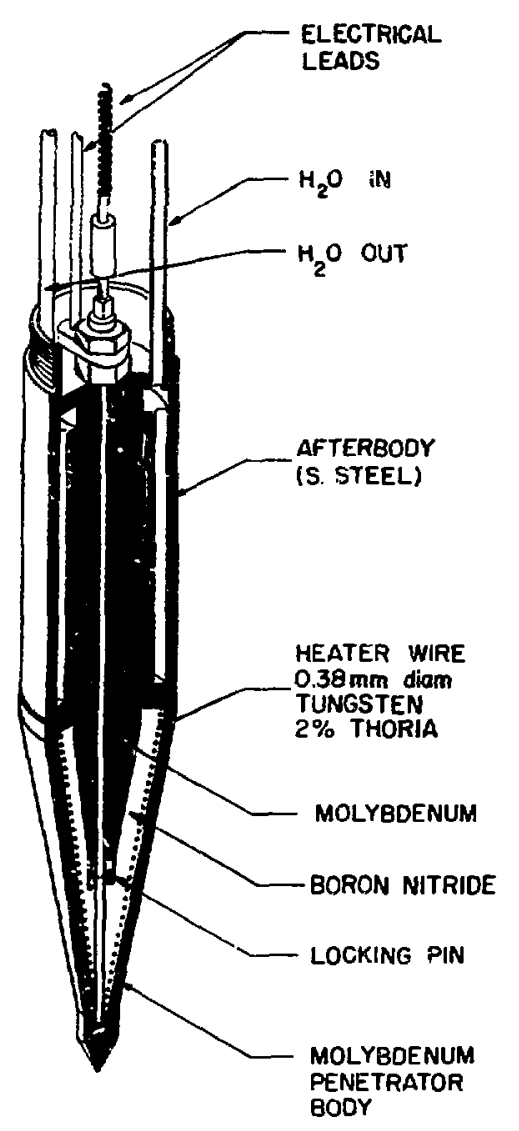

Fig. 2. Consolidation penetrator with tungsten wire heater.

molybdenum, and $\mathrm{BN}$, as well as by initial fabrication steps, could easily reduce this high heat flux locally, causing local overheating of the wire. The literature suygests an upper temperature limit of - 2200 $\mathrm{K}$ (slightly more than $300 \mathrm{~K}$ above the indicated average operating temperature) to keep chemical reaction between tungsten and BN to acceptable levels, 9,10

\section{Split Tungsten Rod}

The search for a rugged, easily fabricated heat source led to the development of split tungsten-rod heaters as shown

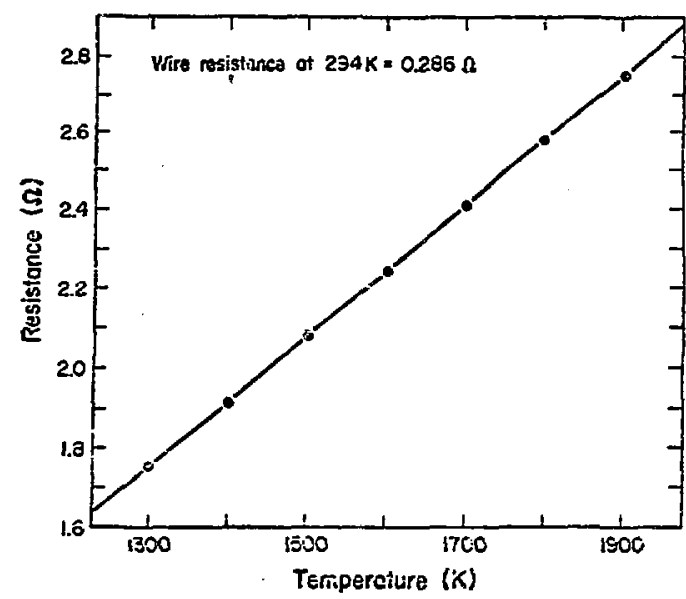

Fig. 3. Temperature deperdence of the resistance of a tungsten heater.

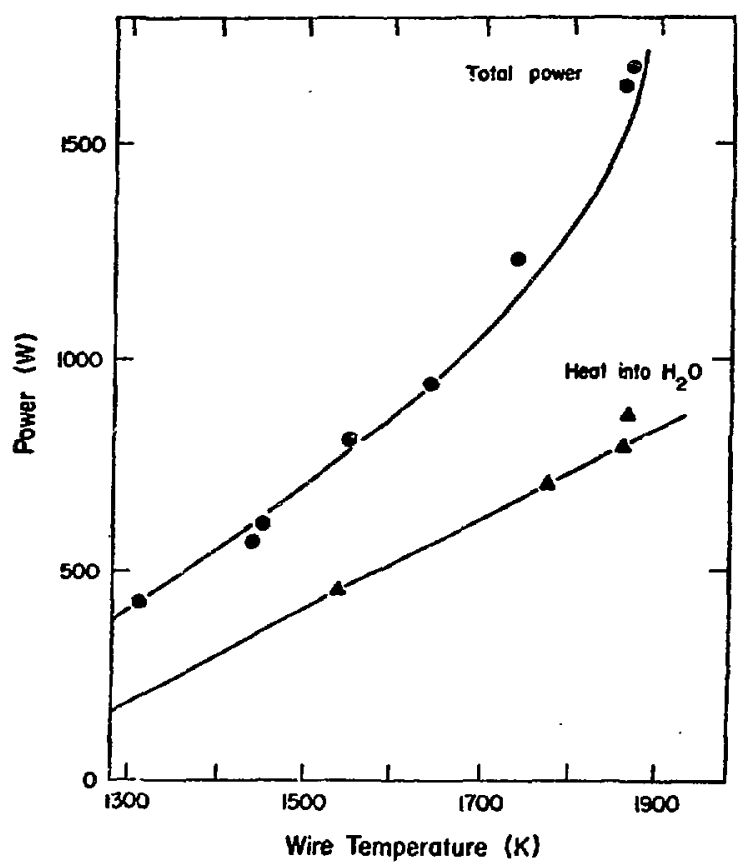

Fig. 4. Relation between power input, power lost to the $\mathrm{H}_{2} \mathrm{O}$ coolant, and tungsten wire temperature. 


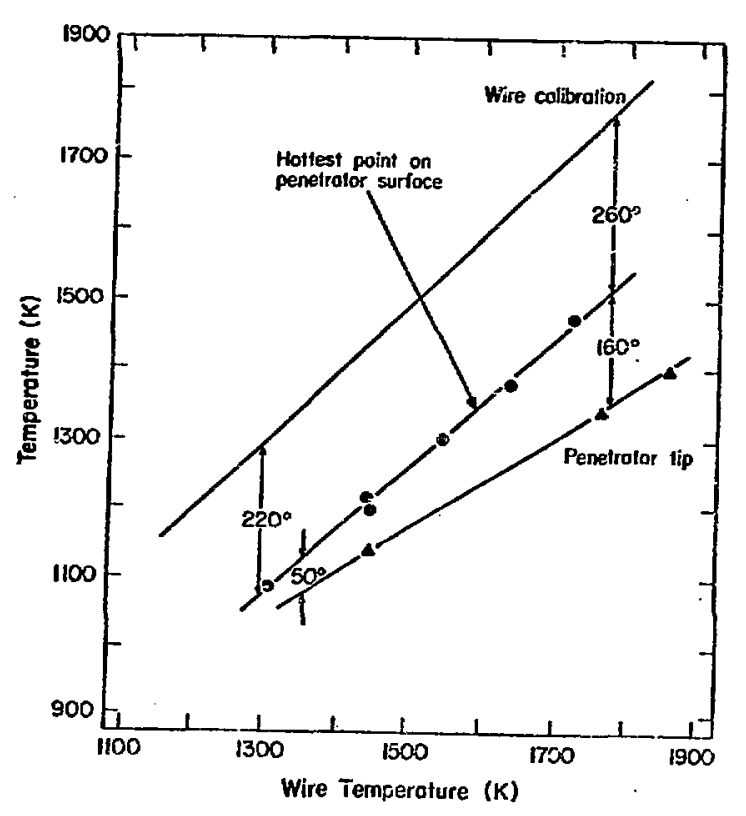

rig. 5. Penetrator temperatures vs tungsten wire-heater temperature.

in Figs. 6 and 7. A laboratory "rock punch" consisting of a 150-mm-1ong by 19-mm-diam tungsten rod split axially by a saw-cut into two semicircular conductors was the first penetrator of this type to be used. When heated by a low-voltage $60-\mathrm{Hz}$ as supply furnishing $\sim 2000 \mathrm{~A}$ at $1.0 \mathrm{~V}$, the unit reached rock-melting temperatures and produced many shallow holes in a variety of rock samples.

\section{Flat Tungsten Ribbon}

Solid rock penetrators require some means of disposing of the melted rock. When this rock is removed by upward flow through a central passage in the penetrator it is desirable to concentrate the heat generation in a flat face heater (Fig. 8). A flat tungsten sheet was milled to produce a heater with relatively high resistance, thereby reducing both the current required (and thus the cross-sectional area of the electrode pin) and the subsequent heat loss to the stein.

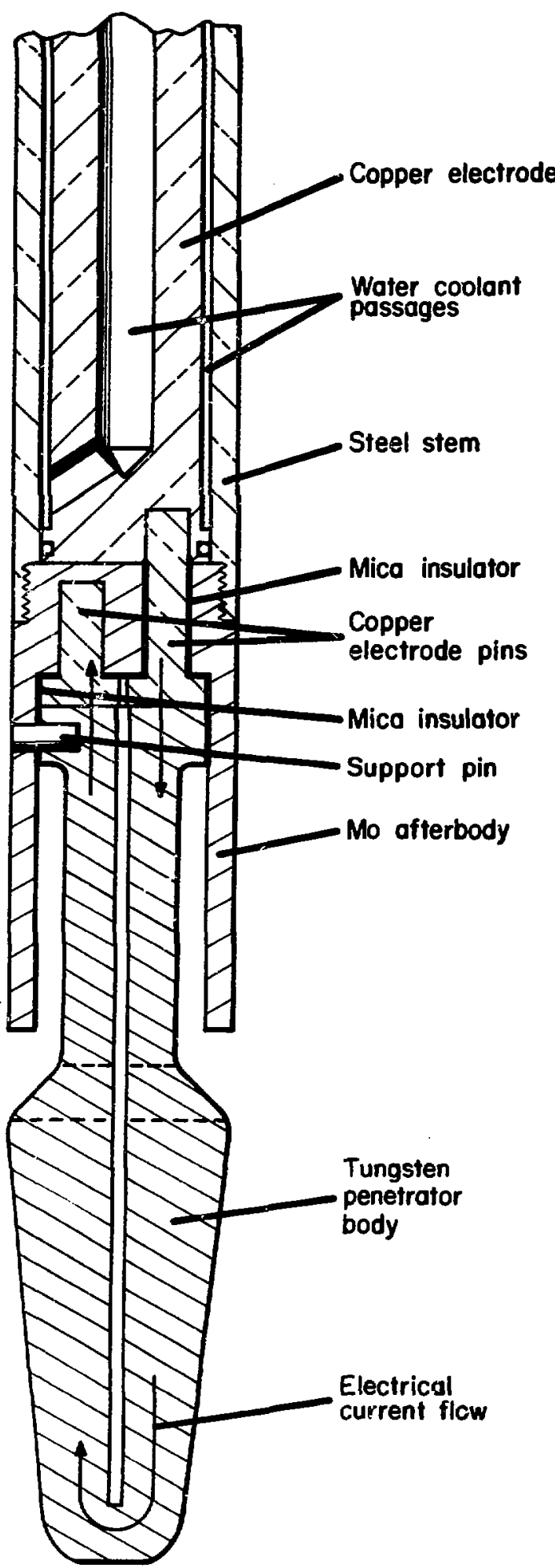

Fig. 6. Split tungsten-rod 25-nm-diam penetrator. 


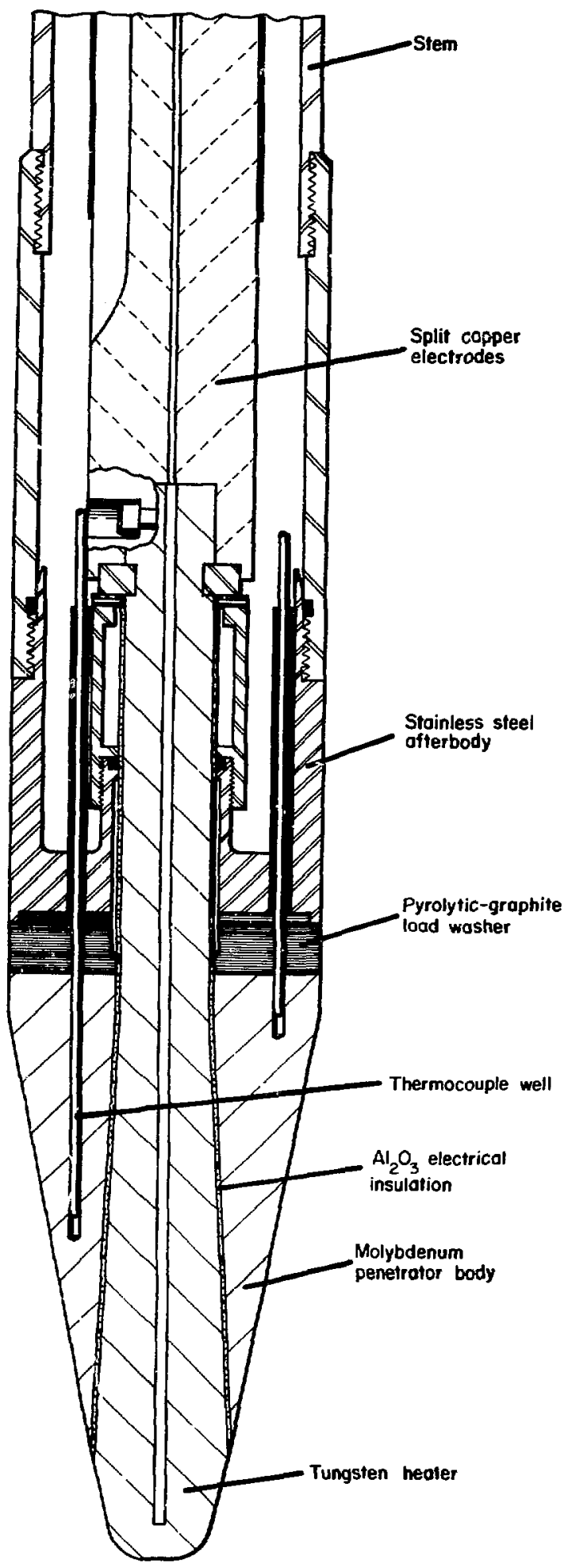

Fig. 7. Split tungsten-rod heater, 50-mmdiam penetrator.
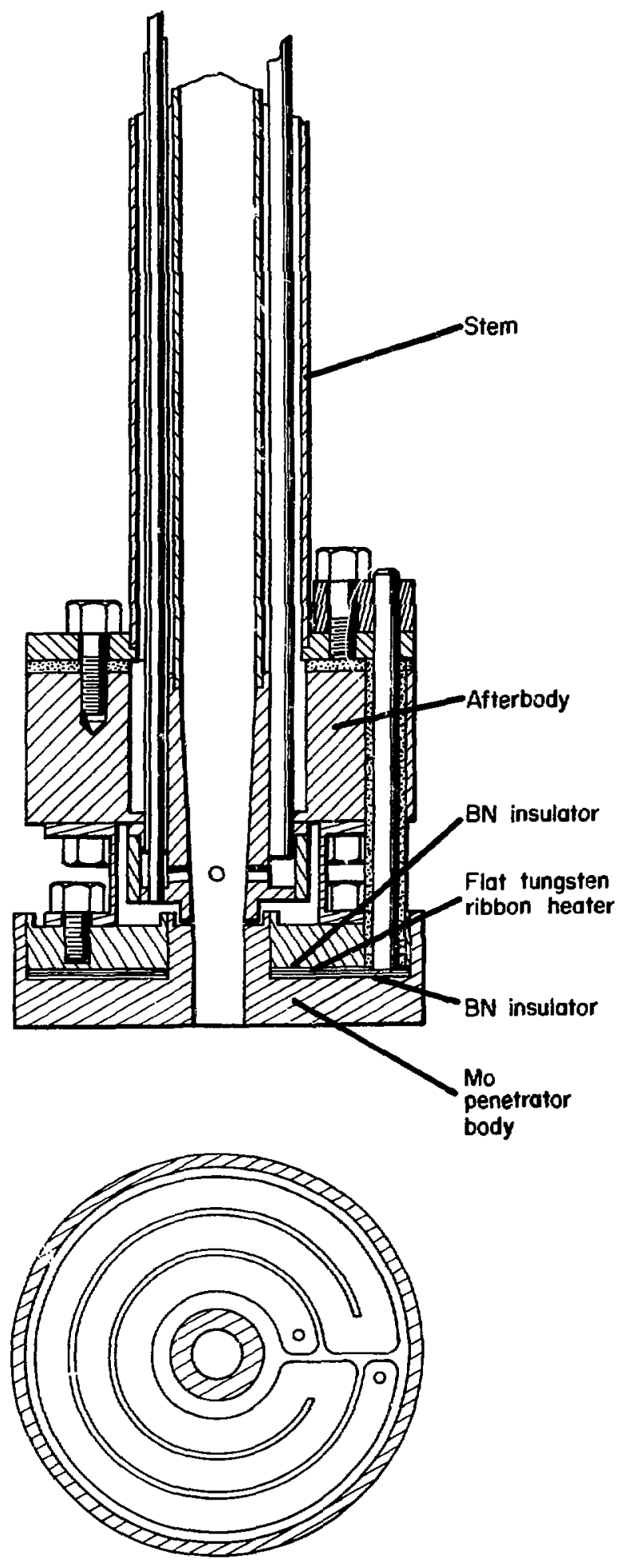

Fig. 8. Flat tungsten ribbon heater, 50-mmdiam penetrator. 


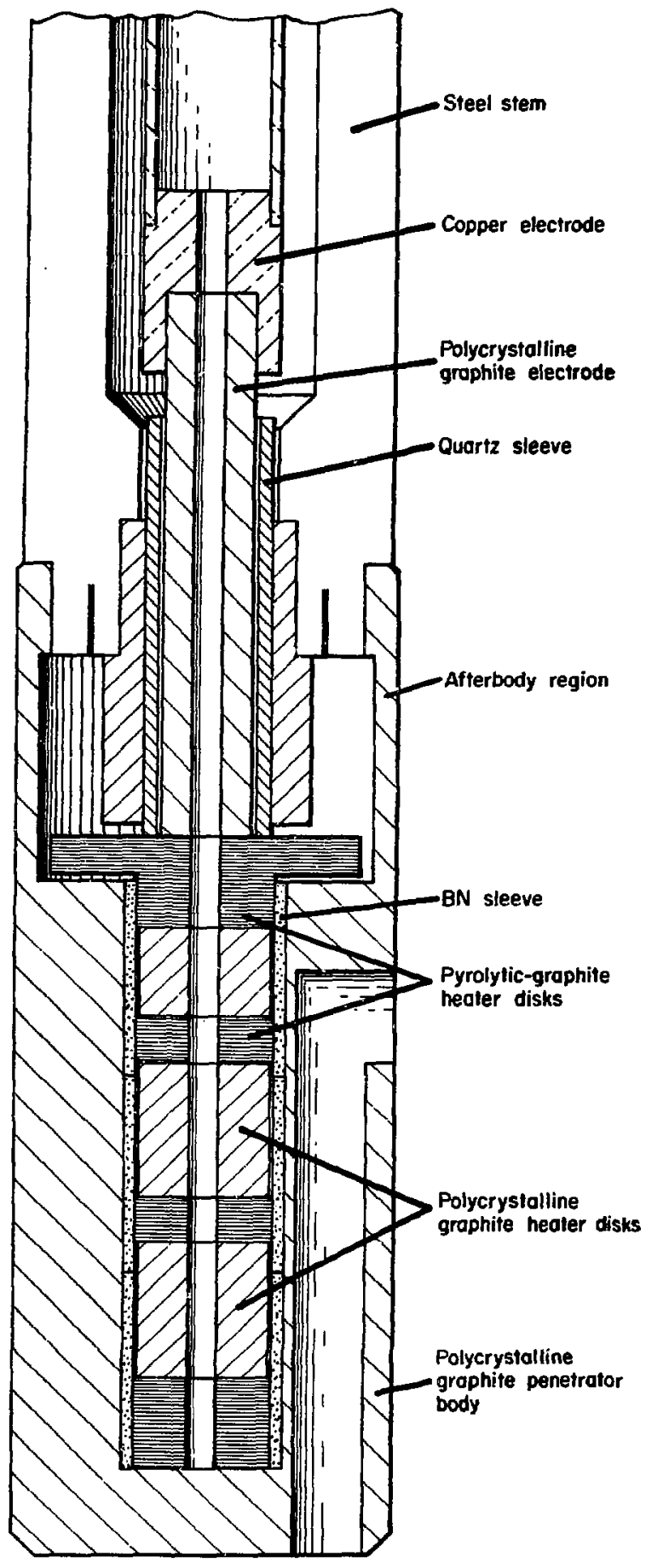

Fig. 9. Graphite-iody 50-mm-diam consolidation penetrator with conduction heater.

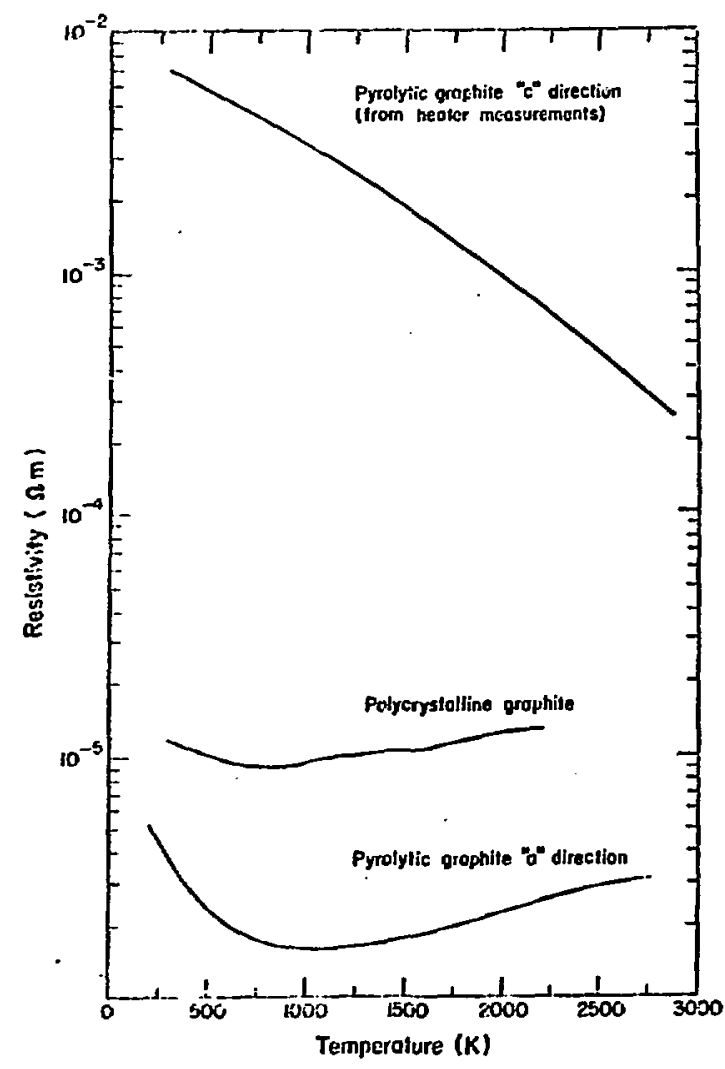

Fig. 10. Electrical resistivity of ijrolytic and polycrystalline graphite, (data from Refs. 9 and 10 ).

B. Graphite Element Conduction Heat-Transfer lieaters and Prototype Penetrators

1. Polycrystalline-Pyrolytic Graphite Heater stack

Tungsten and molybdenum combine properties that make these metals most suitable among readily available materials for penetrator bodies. However, polycrystalline graphite reacts slowly enough with rock melts to be a useful material for fabrication of exploratory prototype designs. One such design is shown in Fig. 9. The heater was composed of alternating disks of pyrolytic graphite and polycrystalline graphite, stacked in a boron-nitride-lined cavity. This unit was operated in a tuff rock sample primarily to study the flow of 


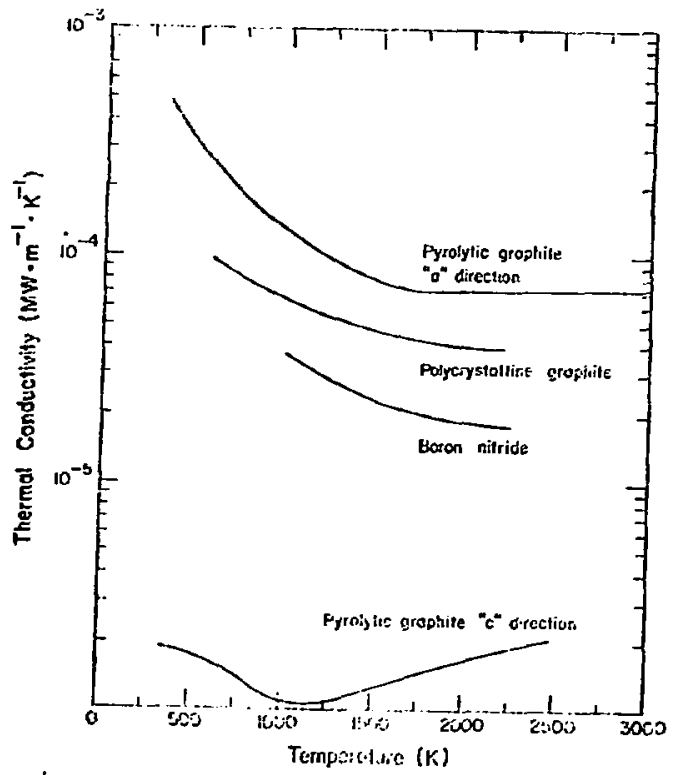

Fig. 11. Themal conductivity of pyrolytic graphite, polycrystalline graphite, and boron nitride. (Data from Ref. 9, 10, 11).

molten rock in internal channels, and was also the precursor of the stacked-disk pyrolytic heater element described below.

The BN sleeve afforded a radial heatconduction path while functioning as an electric insulator. The resistance of the stack could be varied by the mix of pyrolytic and polycrystalline disks. The axial power distribution in the heater stack could also be adjusted by drilling out center holes in selected disks. This configuration provides a high degree of design flexibility because the electrical and thermal properties of pyrolytic graphite, $\mathrm{BN}$, and polycrystalline graphite are widely different, as indicated in Figs. 10 and 11 .

\section{Penetrator Design with Pyrolytic- Graphite Disk stacked Heater The relatively stable behavior of} graphite combined with $B N$ was subsequently utilized in several penetrator desijns fabricated from molybdenum. one unit is shown in Fig. 12. Typical operation in

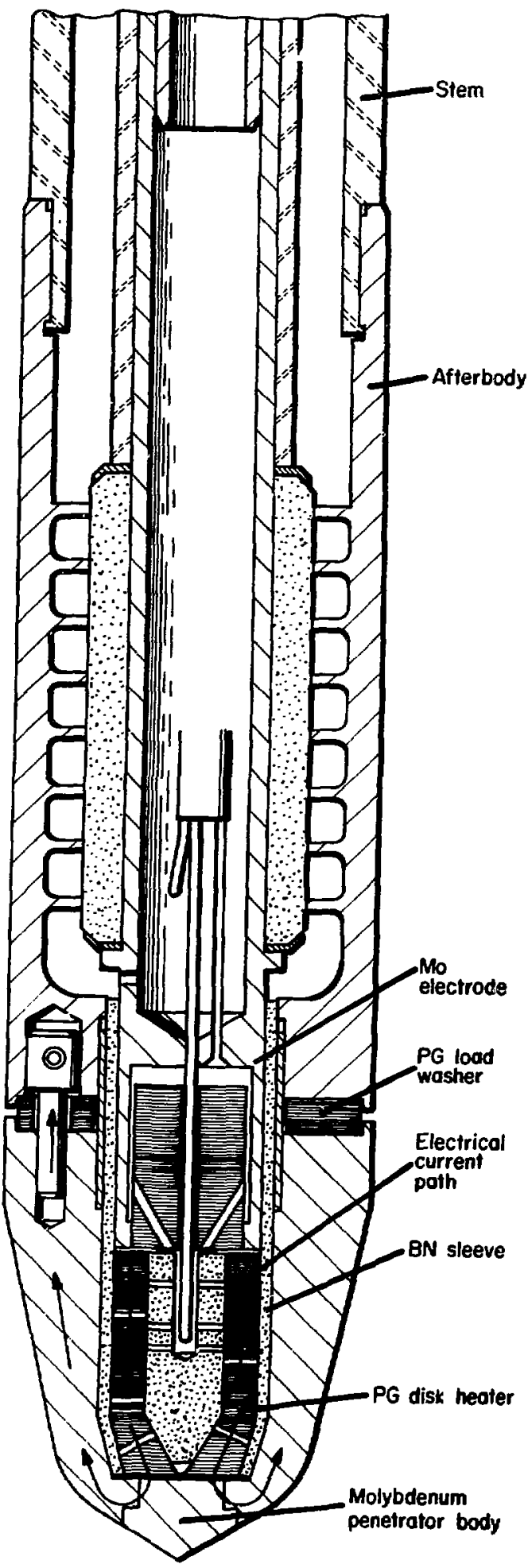

Fig. 12. Pyrolytic-disk stacised heater, 50-mm-diam penetrator. 


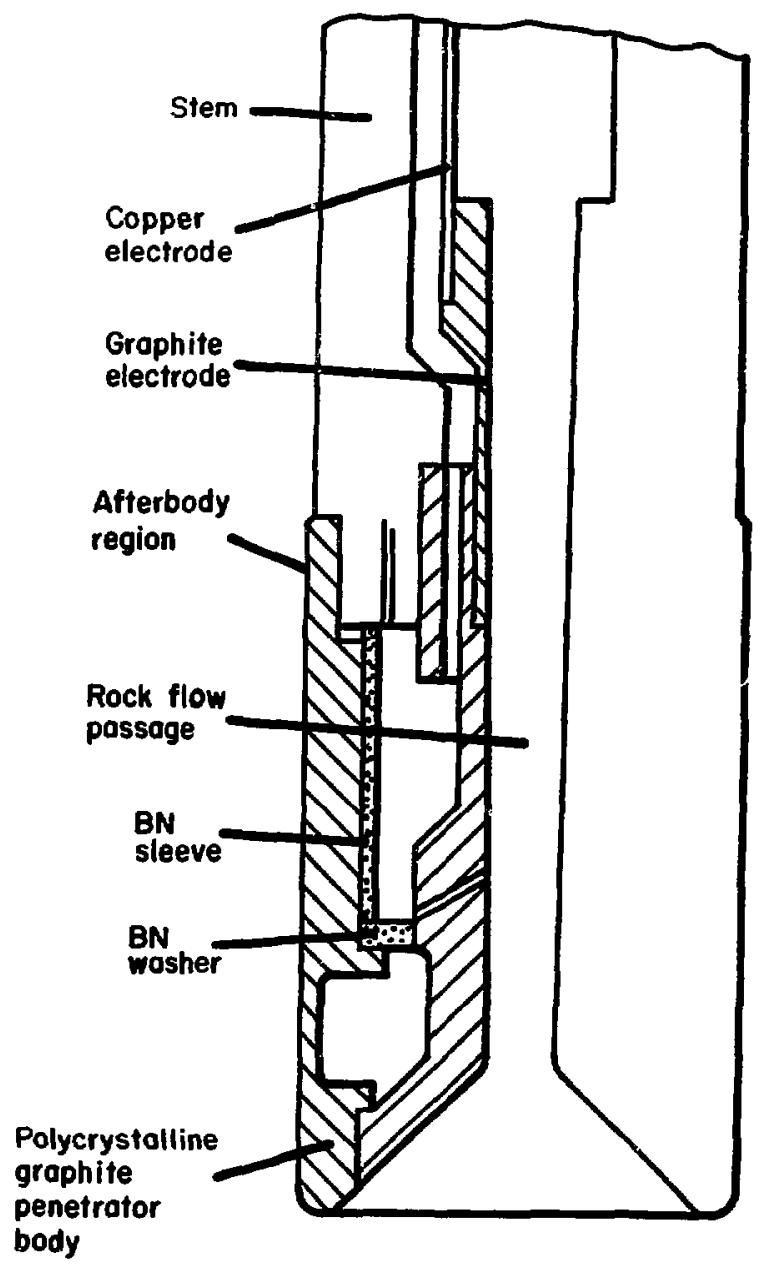

Fig. 13. Direct-resistance heated 50-mmdiam graphite penetrator.

tuff required a heater current of $270 \mathrm{~A}$ at $12 \mathrm{~V}$ (power, $3240 \mathrm{~W}$; resistance, $0.043 \Omega$ ) for an advance rate of $=0.0085 \mathrm{~mm} / \mathrm{s}$. The resulting heat flux from the surface of the pyrolytic-graphite heating element was $\sim 1.5 \mathrm{MW} / \mathrm{m}^{2}$ at an estimated heater temperature of $2200 \mathrm{~K}$ and penetrator surface temperature of $1700 \mathrm{~K}$.

\section{Direct Heating in Graphite Penetra- tor Bodies \\ Ease of machining suggested that} polycrystalline graphite could be used to rapidly and cheaply evaluate both the

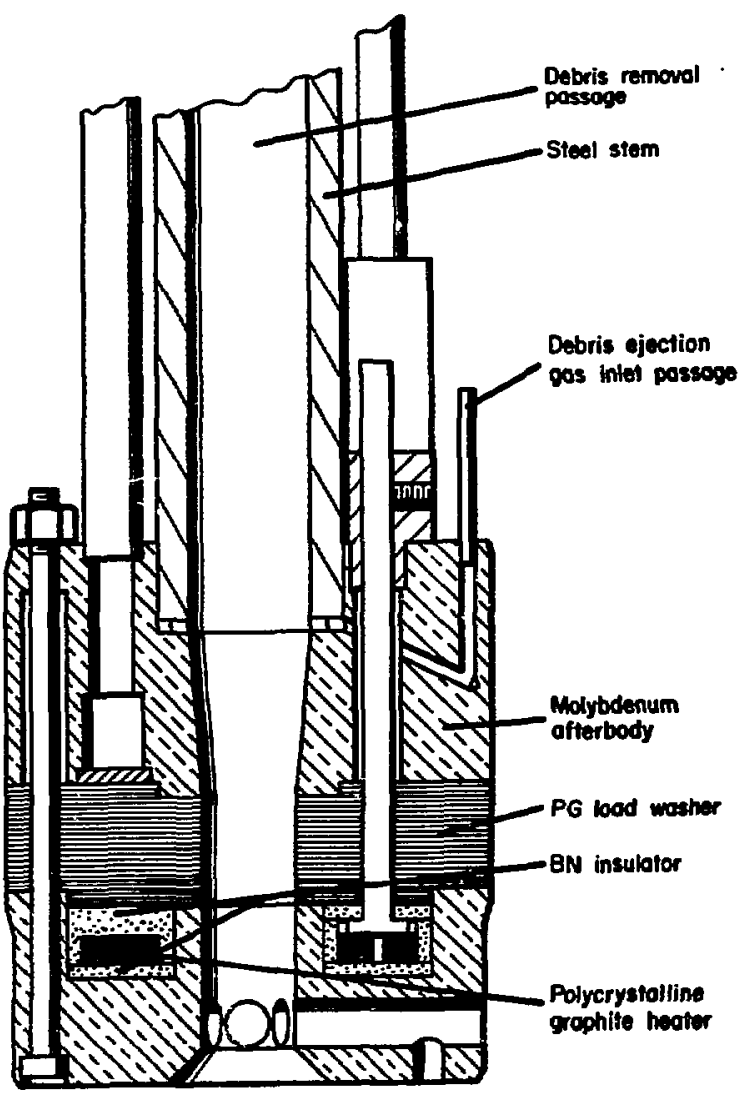

Fig. 14. Helical polycrystalline-graphite ribbon heater penetrator.

outer-surface shapes of penetrators and any promising schemes to handle the rock melt. One such assembly is shown in Fig. 13. The graphite penetrator bocy is self-resistanceheated by current flowing down the outer shell and returning along the inner cylinder. Power generation and the resultant outer-surface temperature were controlled by variations in cross-sectional area. These variations were obtained by machining the internal surface leaying the outer surfaces of the graphite penetrator with the desired geometry for rock-melt flow studies.

\section{Helical Polycrystalline-Graphite Ribbon Heater \\ A 50-mm-diam extruder similar to} that shown in Fig. 1 for use in basalt was designed with a graphite conduction heater. 


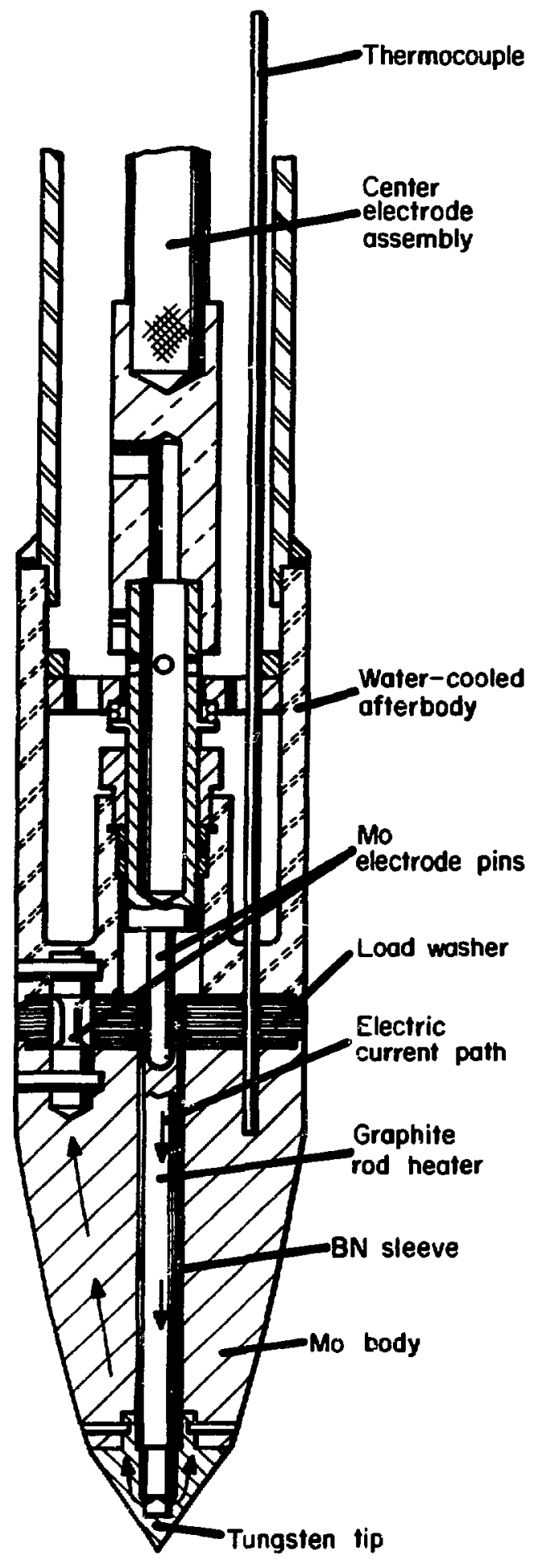

Fig. 15. Axial polycrystalline-graphite rod conduction heater with boronnitride insulator, Model 1.
This unit, shown in Fig. 14, had a flat graphite ribbon heater inbedded in a cavity lined with boron nitride. When tested, the unit failed at a power level of $2200 \mathrm{~b}$. Inspection showed that a severe cnemical reaction had occurred in the intericr of the penetrator where graphite, boron nitride, and molybderum were in mutual contact. Subsequent studies of possibie reactions inthis ternary system ${ }^{32}$ supported the experimental evidence that any two of these materials were compatible at penetrator operating temperatures, but the ternary combination would deteriorate rapidly. Heater resistance was $\sim 0.044 \Omega$, requiring $9.8 \mathrm{~V}$ and 220 $A$ for operation at $2200 \mathrm{~W}$ and a heat flux of $0.7 \mathrm{HW} \cdot \mathrm{m}^{-2}$ at the heater surface.

\section{Polycrystalline Graphite Rod Heaters} The relatively good high-temperature compatibility of graphite and boron nitride was exploited in designs with polycrystalline-graphite rod heaters in molybdenum penetrator bodies. Two such designs are shown in Figs. 15 and 16. A small-diameter, 6.35- or 7.94-mm, cylindrical graphite heater was electrically insulated from the molybdenum body by a close-fitting BN sleeve. Typical operating conditions for Mode1-1, Fig. 15, in tuff were $320 \mathrm{~A}$ at 8.3 $\checkmark$ for a penetration rate of $0.014 \mathrm{~mm}^{-1}$. Total power was $\sim 2650 \mathrm{~W}$ and the resistance of the heater was $-0.026 \therefore$. The corresponding heat flux at the heater surface was $1.6 \mathrm{MW} \cdot \mathrm{m}^{-2}$. The lifetime of this heater appeared to be limited by chemical reaction between the graphite and $\mathrm{BN}$ at the heater BN interface. The Model-2 heater, Fig. 16, was the result of designing for a longer lifetime. Heater temperature was reduced by increasing the heat-transfer area, and the heater surface was coated with TaC to provide a diffusion barrier to the $B N+C$ reaction. The unit operated at $360 \mathrm{~A}$ with $10 \mathrm{~V}$ at a penetration rate of $0.011 \mathrm{~mm} \cdot \mathrm{s}^{-1}$. Total power was $3600 \mathrm{~W}$ and the heater resistance was $0.030 \mathrm{~s}$. The lower penetration rate was probably the restilt of lower 


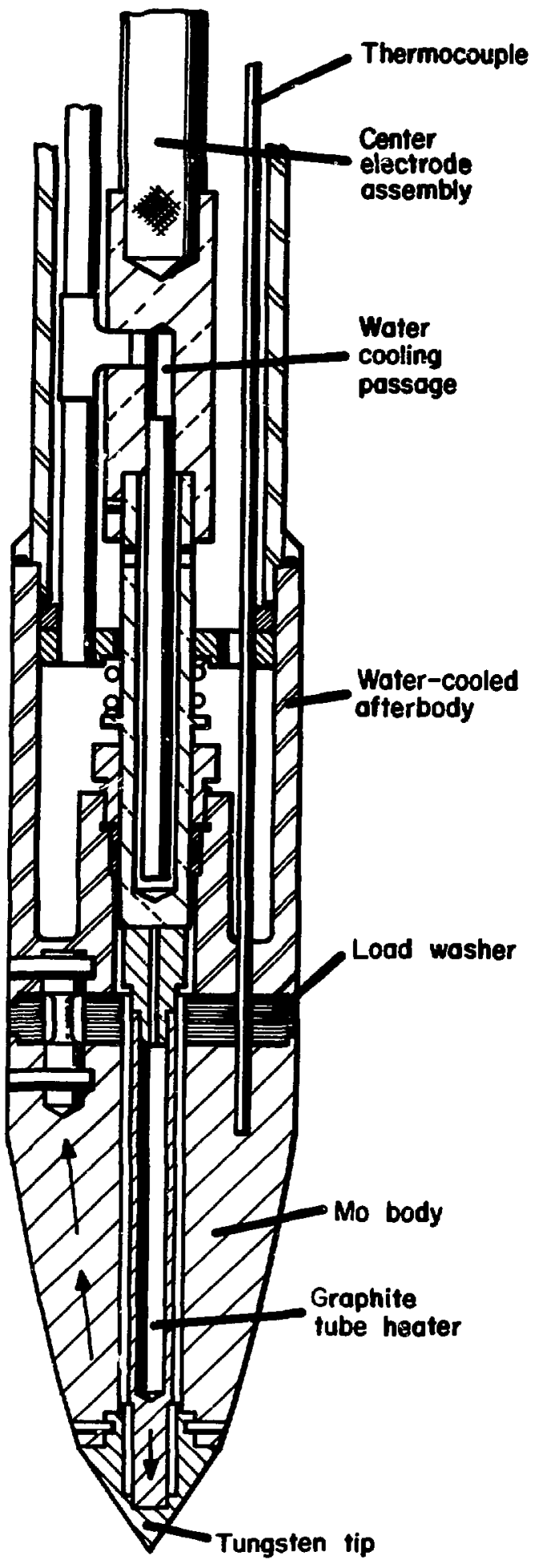

Fig. 16. Axial polycrystalline-graphite rod conduction heater with boronnitride insulator, Model 2. body surface temperatures in spite of a higher power level. Changing the pin shape of the molybdenum electrode (not shown in the drawing) increased the retraction-load capability at the expense of greater heat loss to the stem. The heat flux at the heater surface for this design was $1.58 \mathrm{MW}$ $\mathrm{m}^{-2}$ at the higher power level of $3600 \mathrm{w}$.

\section{Graphite-Element, Radiation Heat-Trans- fer Heaters \\ 1. Graphite Helix \\ Arother approach to solving the} problen of materials compatibility was to replace solid electric insulators with gas and to transfer heat primarily by radiation. Polycrystalline graphite, with its relatively high electrical resistance and high thermal emissivity, was used as the radiating element in a series of radiant-heater designs. One of these heaters was in the shape of a helical ribbon with uniform cross-sectional area as shown in Fig. 17. Tests of the heater with the penetrator body removed revealed problems in producing uniform temperatures along the helix and in preventing electrical breakdown in the upper electrode-attachment assembly. A clearer understanding of these problems was gained from subsequent electron enission measurements (see section III). This heater operated briefly at temperatures up to $2300 \mathrm{~K}$ with $36 \mathrm{~A}$ at $102 \mathrm{~V}$, yielding a power of 3670 $W$ and a radiant heat flux at the heater surface of $1.5 \mathrm{Mw} \cdot \mathrm{m}^{-2}$. One advantage of this configuration is its high resistance which allows operation at lower currents. The lower currents can be carried by electrodes with low heat-transfer capabilities, thereby reducing the power loss through the electrodes to the stem.

\section{Graphite Helix in a Heat-Pipe Pene- trator}

A modification of the helical element was used in a penetrator that incorporated a heat-pipe assembly. One test was conducted and terminated when an arc developed between the heater and the inner 


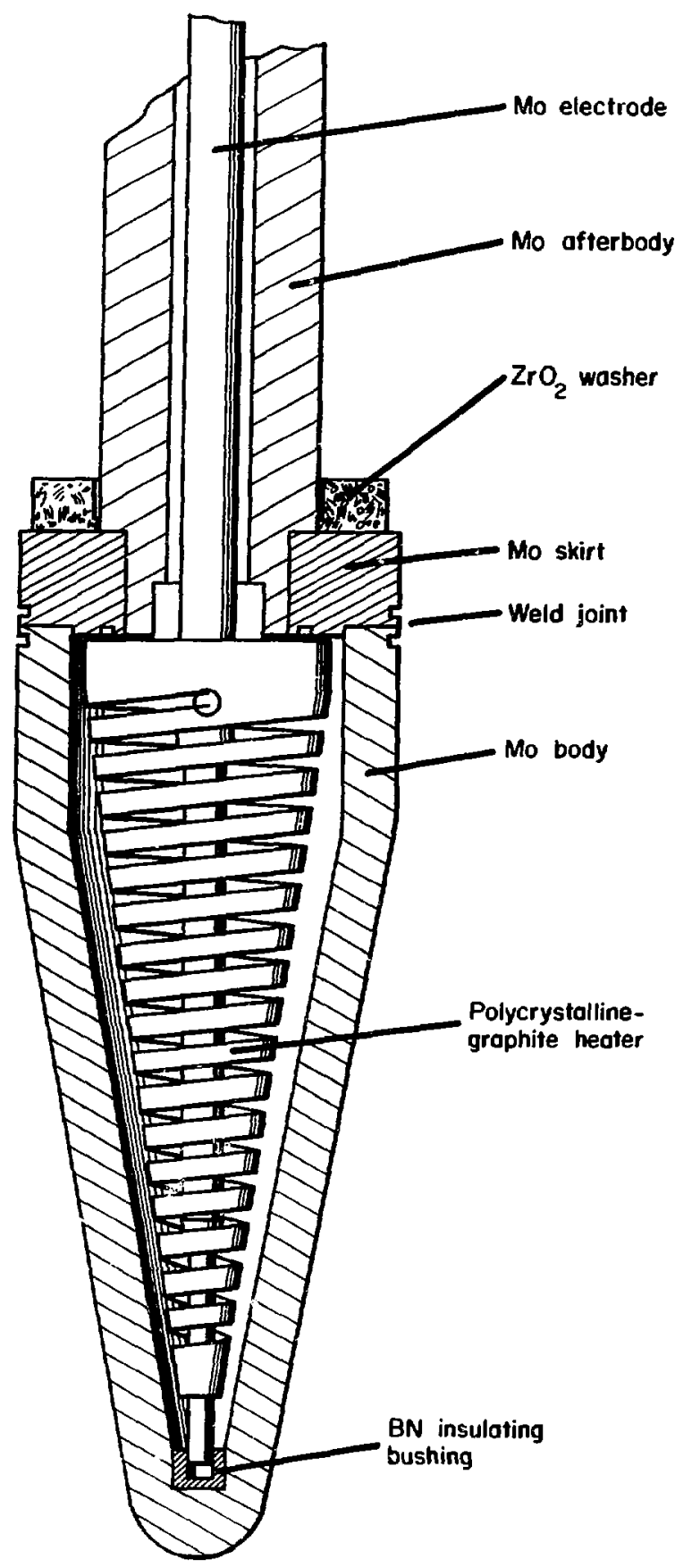

Fig. 17. Consolidation penetrator with graphite-helix radiation heater.

heat-pipe wall. A sketch of this unit is shown in Fig. 18. The heater operated at a maximum power of $3880 \mathrm{~W}$, at $68 \mathrm{~A}$ and 57

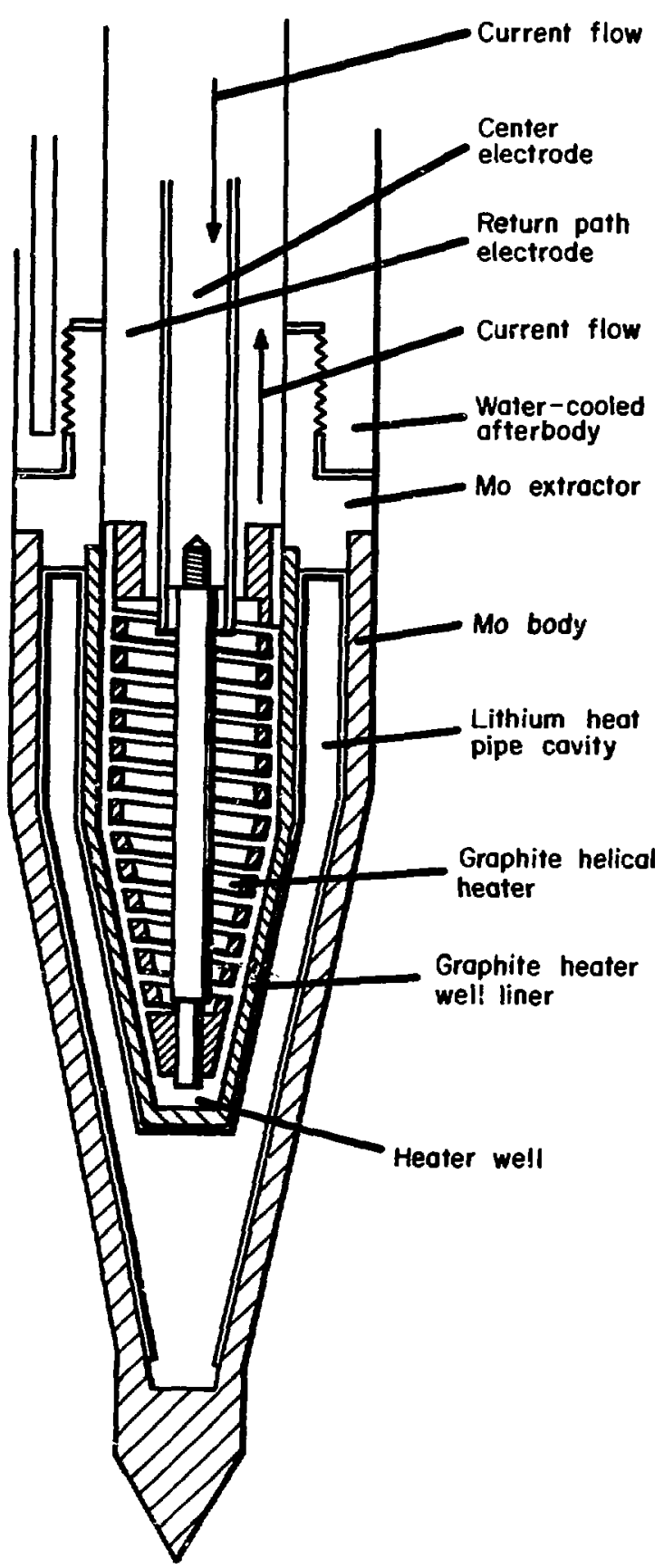

Fig. 18. Consolidation penetrator with helical polycrystalline-graphite heater lithium-heat-pipe cavity.

v. The total resistance was $0.94 \Omega$ and the heat flux at the heater surface was $\sim 2.5$ $M W \cdot m^{-2}$. The heat pipe consisted of the sealed cavity between the heater well and 
the outer molybdenum penetrator body. The heater well was lined with a close-fitting graphite sleeve and was filled with helium gas to improve the heat transfer from the helical heater to the inner molybcenum wall of the heat pipe. The cavity was 1 ined with a fine-mesh screen, also of molybdenum, and was partially filled with lithium metal. At operating temperatures the lithium evaporated from the inner surfaces next to the heater well and condensed on the colder outer surfaces. Capillary action of the wire mesh caused the liquid to flow up and around the top of the cavity to the inner wall, completing the heat-transfer cycle of evaporation with attendant heat pickup and condersation with attendant heat release. Observations of the outer surface of the peretrator at the maximum temperature attained $(1580 \mathrm{~K})$ indicated an almost isothermal condition. Unfortunately, the test terminated before the rock sample could be completely penetrated.

\section{Pyrolytic-Graphite Stacked-Disk Heaters}

a. Inicial Development and Final Configuration

The successful use of pyrolytic

graphite as a heating element and the apparent low thermal resistance of a polycrystalline-graphite radiation receptor were combined to produce a very stable heater assembly. The heater was a stack of pyrolytic-graphite disks held in a graphitelined cavity by a spring-loaded graphite electrode. Several tests were conducted with this configuration in penetrator bodies that previously had been used with axial qraphite conduction heaters. The results of these tests led to the design of a rugged body, heater, and stem assembly for field-test use. A series of 50-mm-diam holes in tuff reaching a maximum depth of $26 \mathrm{~m}$ has been produced and heater operation times in excess of $50 \mathrm{~h}$ have been attained. Fig. 19 shows the construction of this unit.

The main parts are the stem, the gascooled afterbody, the pyrolytic-graphite insulating load washer, the molybdenum body, the molybdenum withdrawal structure or extractor, the polycrystalline-graphite radiation receptor, the pyrolytic-graphite heater stack, the graplite electrode, and the spring-loaded electrode connector. The electrocie anc electrode connector are electrically insulated from the withdrawal structure, afterbody, and stem by boronnitride sleeves.

In operation, direct current is supplied from a rectified and filtered singlephase 60-Hz source. The current path is down the center stem conductor, through the spring-loaded electrode connector to the graphite electrode, down the electrode to the pyrolytic-graphite stack, through this stack to the molybdenum penetrator body, back up the body to the withdrawal structure, and through this structure to the afterbody and outer stem. The center conductor is made positjve with respect to the outer stem, so that within the heater cavity the heater stack is positive with respect to the graphite receptor. Thermal electron emission from the stack is thereby suppressed, reducing the tendency for arcing between stack and receptor. The cavity is filled with helium supplied through a small-diameter tube (not shown) which is led down the hollow center conductor to the top of the graphite electrode. A very small but finite flow of helium is forced into the cavity and out the leakage paths around the threaded connection to the withdrawal structure, and around the boron-nitride electrode-centering sleeve. The afterbody and the stem are cooled by nitrogen gas flow down inside the center conductor. through a series of small holes in the electrode connector, and back up a doublelead spiral cooling-fin passage in the afterbody. Maximum temperature in the afterbody is held to $\sim 700 \mathrm{~K}$ with a maximum gas temperature of $-500 \mathrm{~K}$ and flow rates of $\sim 0.02 \mathrm{~kg} \cdot \mathrm{s}^{-1}$. Long-term operation lover $50 \mathrm{~h})$ at power levels of $\sim 4500 \mathrm{~W}$ and equivalent heat flux densities of $1.34 \mathrm{MW} \cdot \mathrm{m}^{-2}$ 


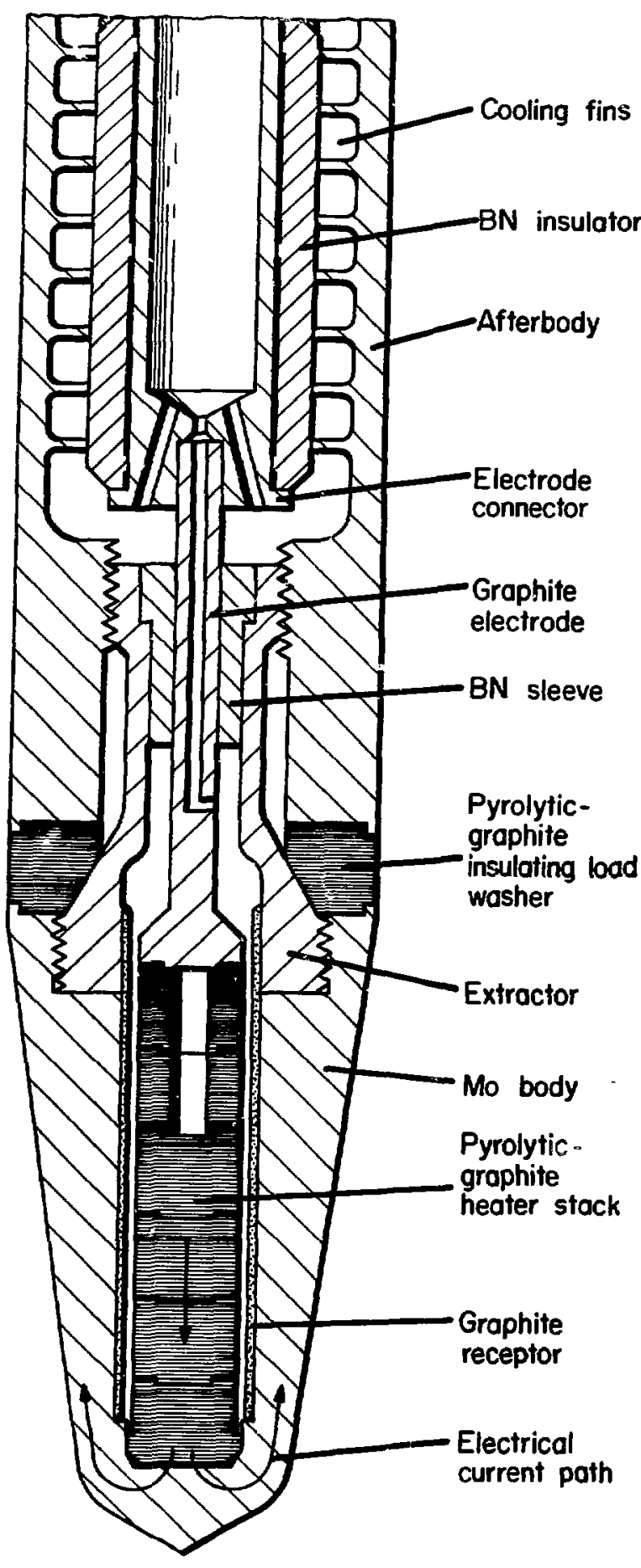

Fig. 19. Fifty-mm-dian field-use penetrator with stacked pyrolytic-graphite disk heater. produced no significant deterioration of the heater and receptor. The molybdenum surface next to the receptox showed uniform carburization to depths of $\sim 1 \mathrm{~mm}$. This penetrator assembly has been tested in the laboratory at a power of $5200 \mathrm{~W}$, with $36 \mathrm{~J}$ and $146 \therefore$ and an equivalent heat flux of $1.55 \mathrm{MW} \cdot \mathrm{m}^{-2}$.

The features which contribute to the durability of this design are summarized as follows.

- Nitrogen-gas cooling is more dependable than water-cooling with its attendant risks of leaks.

- Massive withdrawal structure with the heat losses compensated by a long heat path between the penetrator body and cooled afterbody.

- Simple replacement of the penetrator assembly.

- Utilization of the exceptional combination of high compressive strength and low thermal conductivity of pyrolytic graphite (c-direction) for the insulator between the atterbody and the penetrator body.

- A heater cavity containing oniy graphite in the high-temperature region.

- The use of a specialty graphite (POCO Grade AXM) for the receptor whose thermal expansion characteristics match those of rolybdenum.

- A pyrolytic-graphite heater stack oriented so that the high electrical resistivity along the c-axis is parallel to the penetrator axis.

- Hollow heater sections to control relative heat deposition along the penetrator body.

\section{b. Sealed Unit for Field Use}

A modification of the stacked py rolytic-graphite heater penetrator has been prepared for use in a field-demonstration rig. The penetrator assembly and the complete penetrator-and-stem design are shown in Figs. 20 and 21, respectively. The 


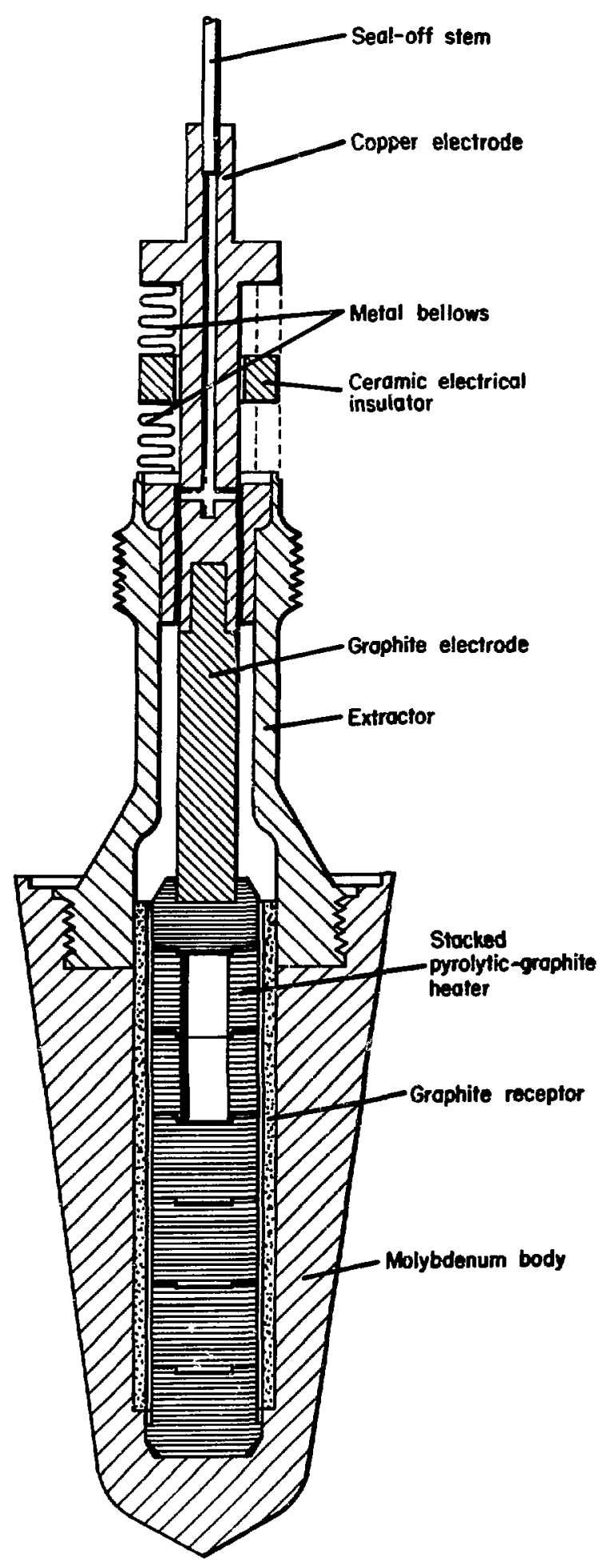

Fig. 20. Sealed unit for field use.

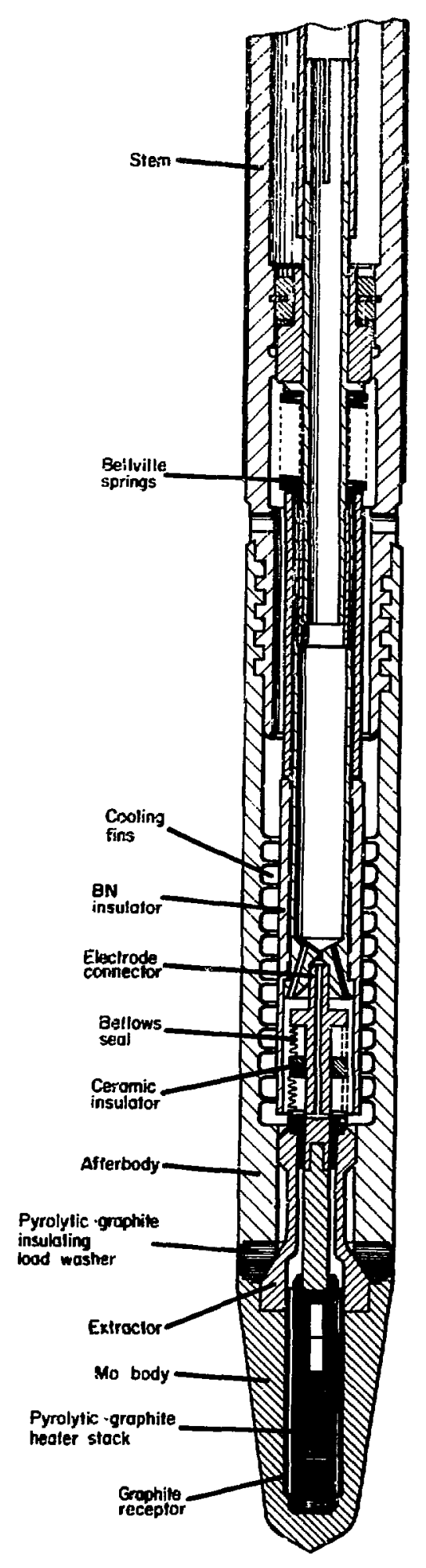

Fig. 21. Sealed unit for field use in place on stem assembly. 
penetrator has been assemoled but has not yet been testec. Significant design features are:

- The penetrator assembly consisting of body, withdrawal structure, and electrode is a hermetically sealed unit, filled with heiium gas.

- The withdrawal structure is sealed to the body by an electron-beam weld.

- The electrode is sealed to and electrically insulated from the withdrawal structure with a stainless-steel bellows and an alumina spacer. This assembly is attached to the withdrawal structure by vacuum-brazing.

- The withdrawal structure is electroplated with oxidation-resistent platinum, permitting the assembly to be cooled with compressed air.

- Cooling air flows down the inside of the center electrical conductor and Lack up around the stem, in the onnular space between the stem and the glass-lined hole.

\section{c. Long Heater Elements}

Penetrators operating in the consolidating mode in which the melt is yushed into cracks of the surrounding rack rather than removed up the stem are power-limited in advance rate. ${ }^{13}$ Materials compatibility places an upper limit on penetrator temperatures, and heat flow through the molten glass to the rock/glass incerface places a limit on the heat flux at the penetrator surface. Increased penetration rates consequertly depend on increasing tile penetrator surface area or changing the penetrator geomeiry. A long penetrat.r body was fabricated, as shown in $F$ ig. 22. to provide experimental data for this power relationship. Matchinc the heater resistance to the available power sipply and keeping the heater voltage at an acceptable level were problems encountered. Tests were conducted with a stack of alternating pyrolytic-graphite and polycrystalline-graphite disks, and the

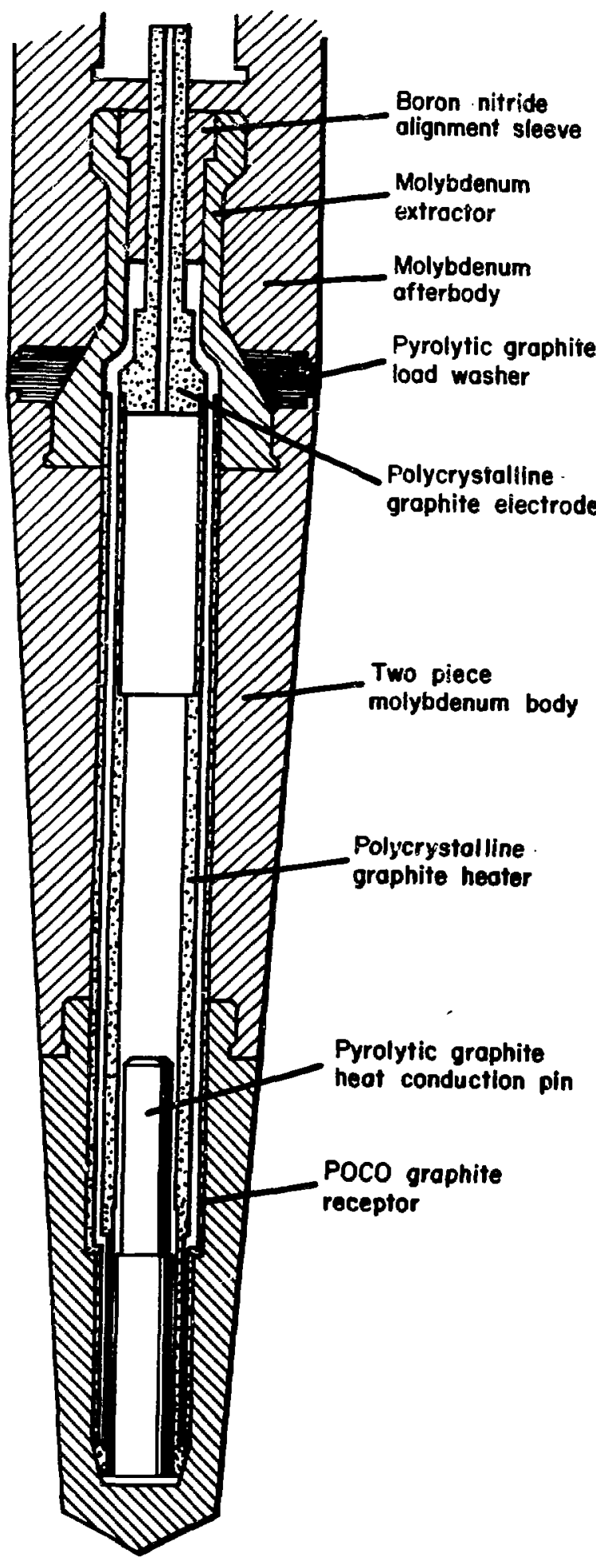

Fig. 22. Long heater element, 51-mm-diam penetrator. 


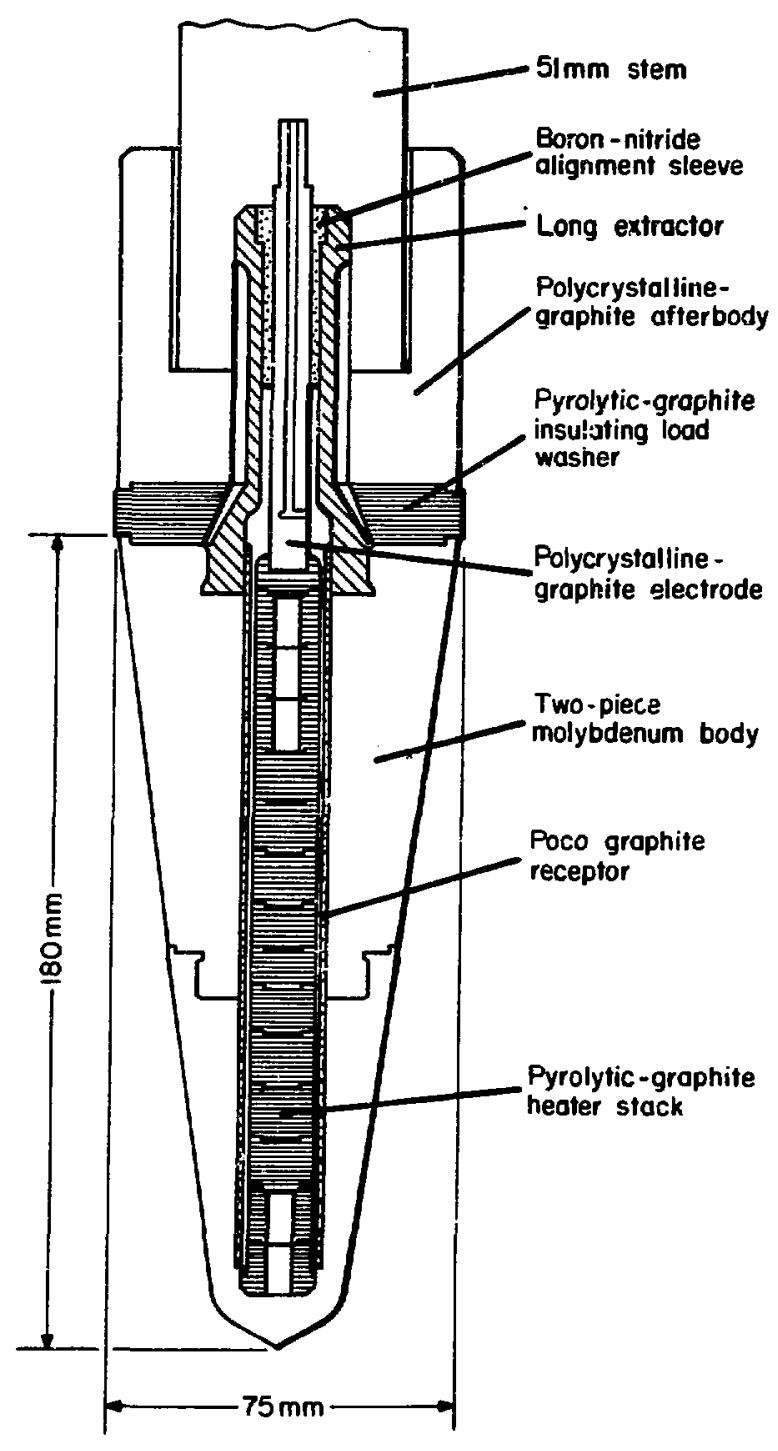

Fig. 23. Consolidation penetrator, 75-mmdiam.

alternative design shown in the figure with a thin-walled polycrystalline-graphite tube heater was prepared and fabricated. The results of the tests in tuff with the alternating disks showed operation at a power of $4500 \mathrm{~W}$, with $45 \mathrm{~V}$ and $100 \mathrm{~A}$, giving a rate of $0.13 \mathrm{~mm} \cdot \mathrm{s}^{-1}$ and a heater-surface heat flux of $0.58 \mathrm{MW} \cdot \mathrm{m}^{-2}$. d. Larger-Diameter Penetrator Designs The consolidating penetrator lends itself to scaling up to larger sizes. A 75mm-diam unit has been constructed and will be tested with a 50-mm-diam stem as shown in Fig. 23. When used in tuff, the unit should produce a 19-mm-thick glass lining. A simplified analytical model of consolidating penetration mechanisms suggests a parabolic shape for the penetrator. The unit approches such a shape and should produce a penetration rate of $0.086 \mathrm{~mm} \cdot \mathrm{s}^{-1}$. This rate compares well with a calculated rate of 0.1 $\mathrm{mm} \cdot \mathrm{s}^{-1}$ for a $50-\mathrm{mm}$-diam penetrator operating at the same penetrator surface temperature of $1773 \mathrm{~K}$.

\section{e. Multiple Heater Stacks Electri- cally Connected in Parajlel Practical considerations sugges-} ted that the rock melt from an extruding penetrator be removed up the center of the stem. This configuration calls for a different heater placement. The negative temperature coefficient of resistance in the c-direction of pyrolytic graphite seemed to preclude the use of individual heater stacks electrically connected in parallel. If the stacks were thermally independent more power would be dissipated in the hotter stack, which, in turn, would increase its temperature, decrease its resistance, and increase its power dissipation. However, the design shown in Fig. 24, when fabricated and tested, provided uniform heating of the penetrator body from its parallel-connected heater stacks. Apparently, the good thermal communication between the heater cavities prevented the anticipated heater unbalanse and potential thermal runaway. The saliert features of this design include:

- A central passage for molten-rock extrusion.

- A blunt-faced penetrator body of reduced diameter.

- Three radial channels for peripheral molten rock to reach the central extruding orifice, and 


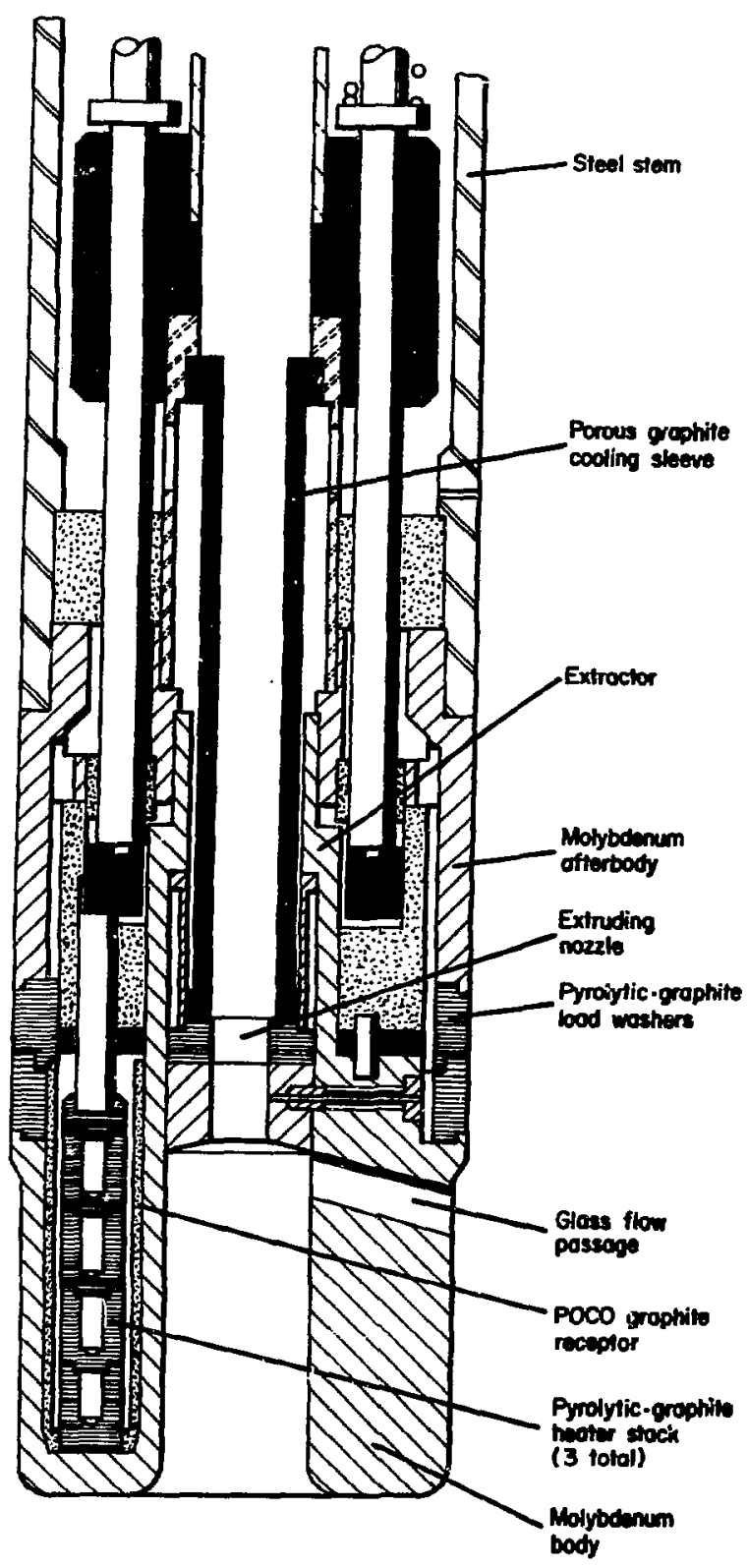

Fig. 24. Multiple-heater-stack of 64-mndiam extruding penetrator.

- Three pyrolytic-graphite heater stacks electrically connected in parallel.

In operation, the unit maintained a penetration rate of $0.07 \mathrm{~mm} \cdot \mathrm{s}^{-1}$ in basalt, at a power input of $\sim 6300 \mathrm{~W}$ with $33 \mathrm{~V}$ and
191 A and a heat flux at the heater surface of $1.65 \mathrm{MW} \cdot \mathrm{m}^{-2}$.

\section{Annular Pyrolytic-Graphite Ring}

a. Alluvium-Coring 57-mm-diam Penetrator

Interest in the demonstration

of a penetrator that would produce a partially unmelted core of unconsolidated alluvium led to the design shown in Fig. 25 . The body was constructed of polycrystalline graphite and contained a pyrolyticgraphite annular heater. The outside diameter of the body was $57 \mathrm{~mm}$ and the bore diameter was $26 \mathrm{~mm}$. The heater cavity was filled with helium gas. Nitrogen gas provided stem and afterbody cooling before passing through a porous copper cylinder into the core-extruding central region. The penetrator body was secured to the outer stem wall by a graphite afterbody through which penetration and extraction forces were applied. Electrical contact was provided by a path down the inner stem tube, through the many-passage core-cooling copper cylinder, and then to a graphite electrode which fitted into the heater. The return path was through the penetrator body. afterbody, and outer stem wall. Electrical insulation was maintained in the heater cavity by boron-nitride sleeves. Thermal insulation between the inner wall of the penetrator body and the core-cooling cylinder was provided by a pyrolytic-graphite apacer. A clamp was attached to the upper stem just below the nitrogen gas inlet. Penetration and extraction forces were transmitted from the laboratory load frame through this clamp. The copper cooling cylinder consisted of a series of bonded 0.8-mm-thick i.isks with 0.08-nm-diam radial grooves embossed on one side. This configuration produced a gas-bearing effect which tended to keeg the core from touching the metal surface as it was extruded up the central tube. 


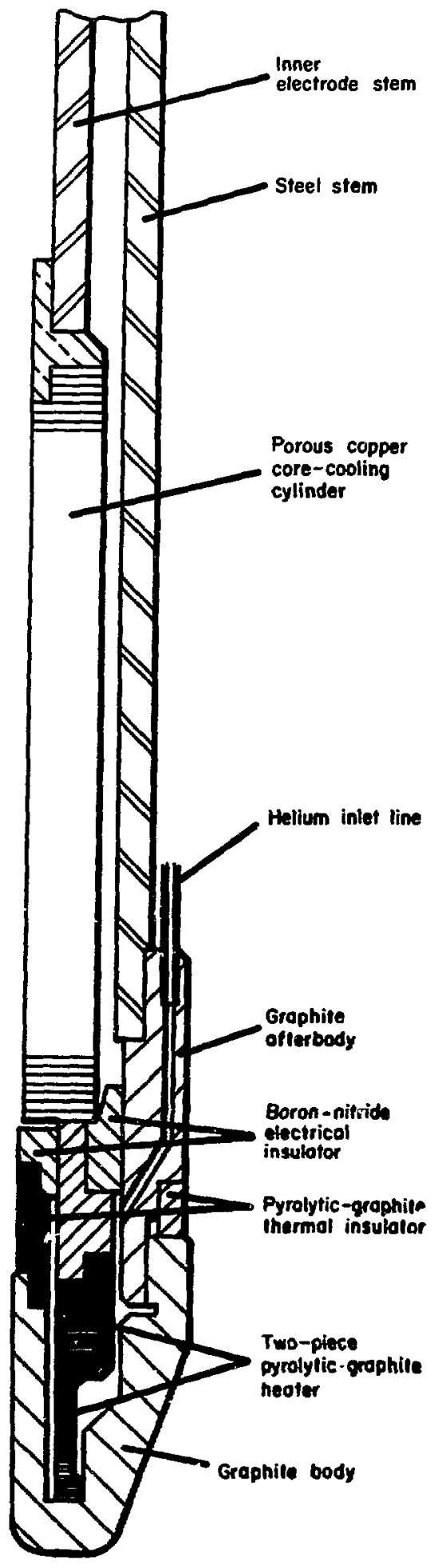

Fig. 25. Alluvium coring penetrator.

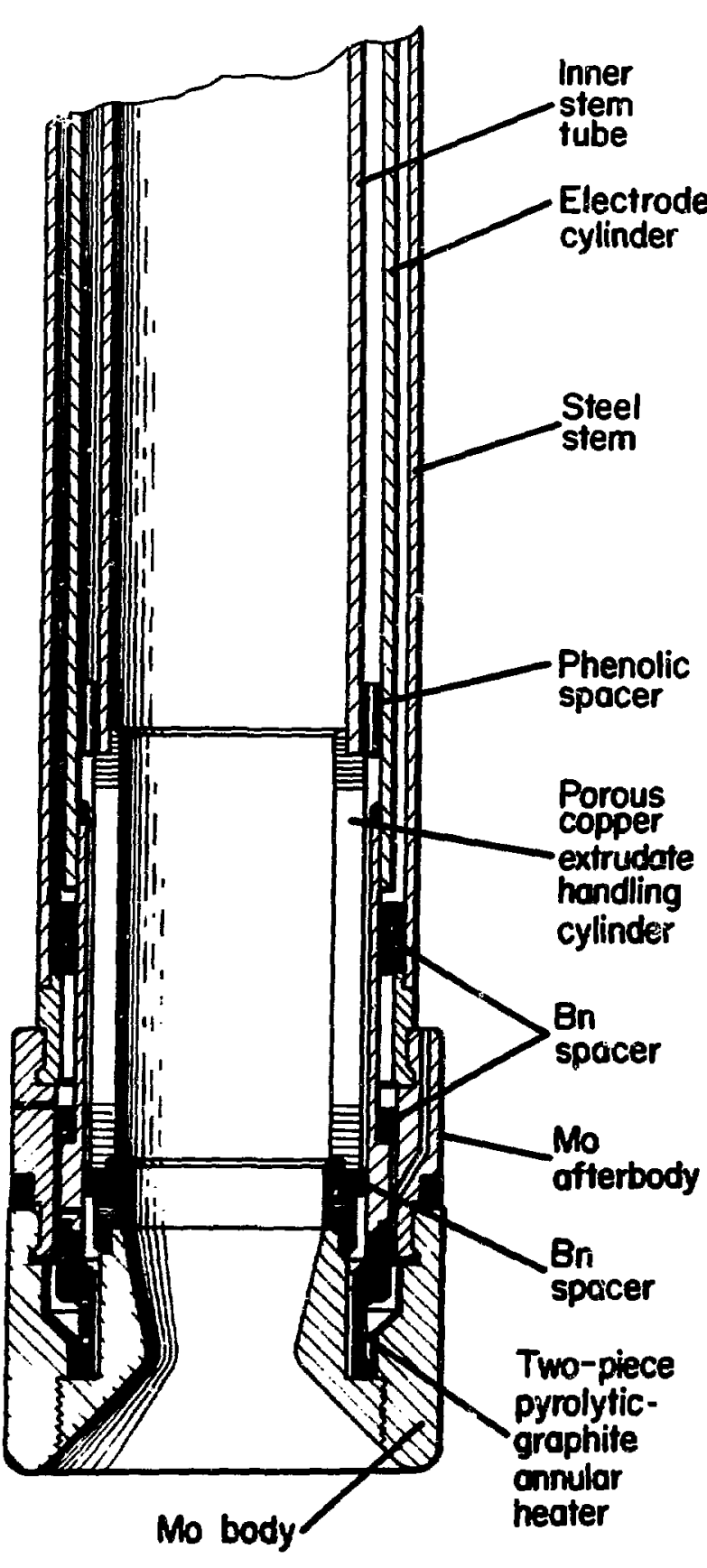

Fig. 26. Sasalt 57-mm-diam extruding penetrator.

When tested in alluvium the unit operated at a power level of $1300 \mathrm{w}$, with a heater resistance of $0.023 \mathrm{~m}$, requiring $5.4 \mathrm{~V}$ and a current of $240 \mathrm{~A}$. The 
corresponding heat flux at the heater surface was $-0.3 \mathrm{MW} \cdot \mathrm{m}^{-2}$. A partially melted core was produced.

\section{b. Basalt Extruding 57-mm-diam Pene- The successful testing of the} graphite-body alluvium cores prompted the design of a basalt-extruding penetrator of the same general configuration. This design, Fig. 26, differed from the preceding unit in that:

- The penetrator body and afterbody were fabricated from molybdenum.

- The penetrator-body leading surface was shaped to direct most of the melt up the interior of the stem.

- A third stem cylinder provided the electrical path to the pyrolyticgraphite heater.

This unit operated at a penetration rate of $0.04 \mathrm{~mm} \cdot \mathrm{s}^{-1}$ with a power level of $4100 \mathrm{~W}$. The current was $305 \mathrm{~A}$ and the voltage was $13.3 \mathrm{~V}$. The corresponding heat flux at the heater surface was $\sim 0.9$ $M W \cdot \mathrm{m}^{-2}$.

\section{c. Basalt-Stripping-Nozzle Extruding Penetrator}

A modification of the basalt-extruding penetrator, Fig. 27, provided for a coaxial gas jet from a small heated nozzle to strip molten rock. This unit was first fabricated from graphite, then from molybdenum with small changes in nozzle configuration. The heater geometry was the same as in the extruding penetrator but the operating power level was increased to $4.8 \mathrm{~kW}$, giving a penetration rate in basalt of $0.05 \mathrm{~mm} \cdot \mathrm{s}^{-1}$ and requiring $280 \mathrm{~A}$ at $17 \mathrm{~V}$. The heat flux at the heater surface was $\sim 1.0 \mathrm{MW} \cdot \mathrm{m}^{-2}$. Posttest examination showed little evidence of heater erosion, but revealed that in two tests an adherent coating of pyrolytic carbon had been deposited on the hottest region of the heater cylinder. Future design can probably eliminate this phenomenon by adequately sealing the heater cavity from molten rock or gaseous impurities.

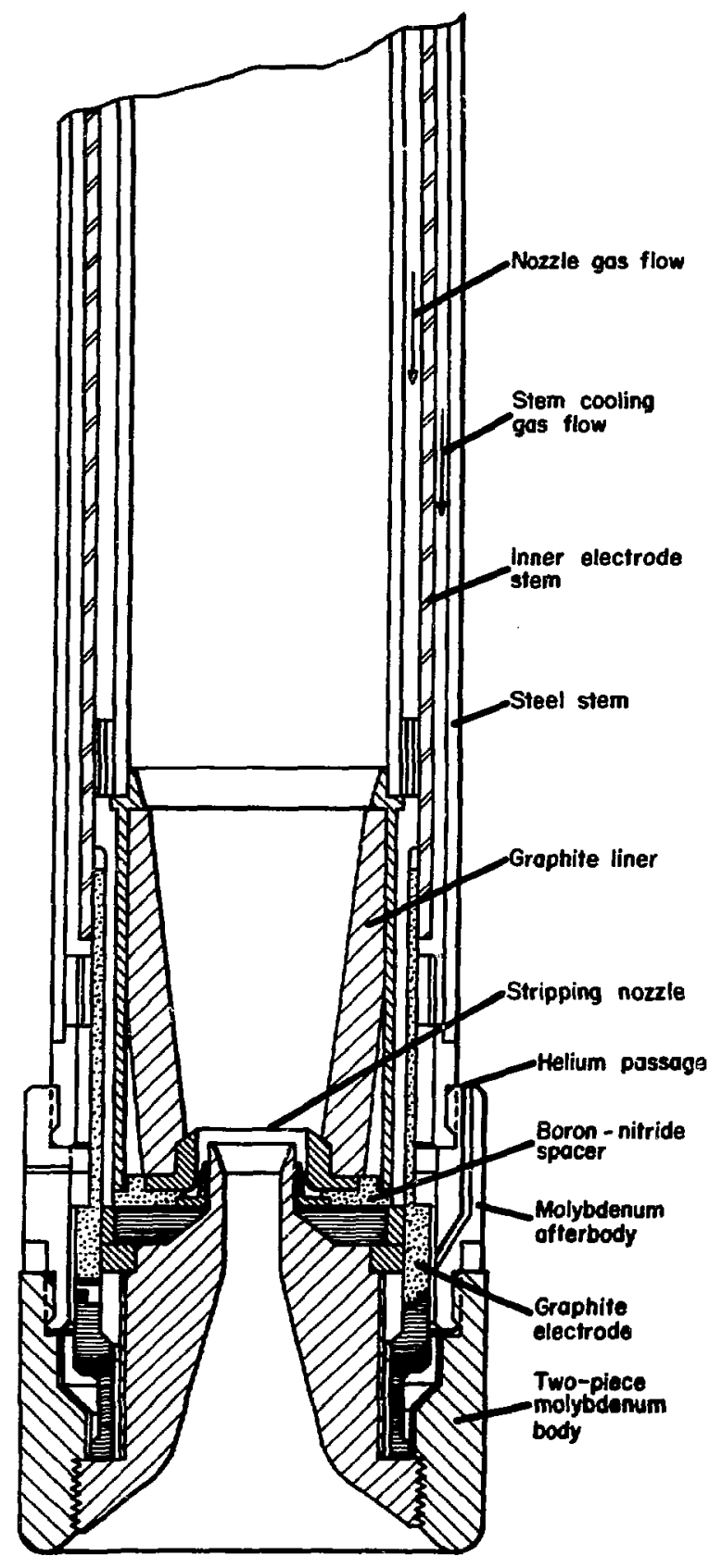

Fig. 27. Basalt-stripping-nozzle extruaing penetrator.

d. Secondary-Heater Extruding PeneErator

Attempts to excrude basalt glass

into cylinders of indefinite length have 
not been successful, mainly because the nozzle structure failed to remove sufficient heat from the melt before extruding it into free space. The problem stems from the fact that the rock-melting process produces a molten glass at a temperature of $~ 1600 \mathrm{~K}$. At this temperature the viscosity of the glass is much too low for proper extrusion. A design has been produced in which enough heat is supplied to the penetrator frontal surface to complete1y melt the rock. The resulting rock-glass is then chilled as it passes through a conditioning section and then is extruded into the removal passage. Initially the conditioning section mist be held at the proper extruding temperature by a second heater, but during operation heat must be renoved from the rock-glass by a wall of the section to a flowing coolant gas. The highly viscous glass leaving the glass-conditioning section is further cooled by a coaxial gas flow. This flow also provides some levitating force to prevent sagging of the extrudate. This rather complicated design has been completed but not fabricated. A drawing of the unit is shown in Fig. 28.

\section{e. Alluvium 114-mm-diam Coring Pene-}

A 114-mm-diam alluvium coring penetrator is being fabricated. This unit is based on the 58-mm-diam coring penetrator described above, except that water-cooling will be used. In operation, the unit will attempt to produce a relatively undisturbed (unmelted) core while forcing most of the melted material ahead of the annular penetrator body out around the penetrator to form a glass wall. The design allows the periodic use of standard core-barrel techniques to remove the stationary cores as the penetrator moves into the rock. The unit is designed to operate at a power level of $25 \mathrm{~kW}$ and a relatively high heat flux at the heater surface of $2.4 \mathrm{MW} \cdot \mathrm{m}^{-2}$ for penetration rates of $\sim 0.1 \mathrm{~mm} \cdot \mathrm{s}^{-1}$. Power requirements are to be satisfied

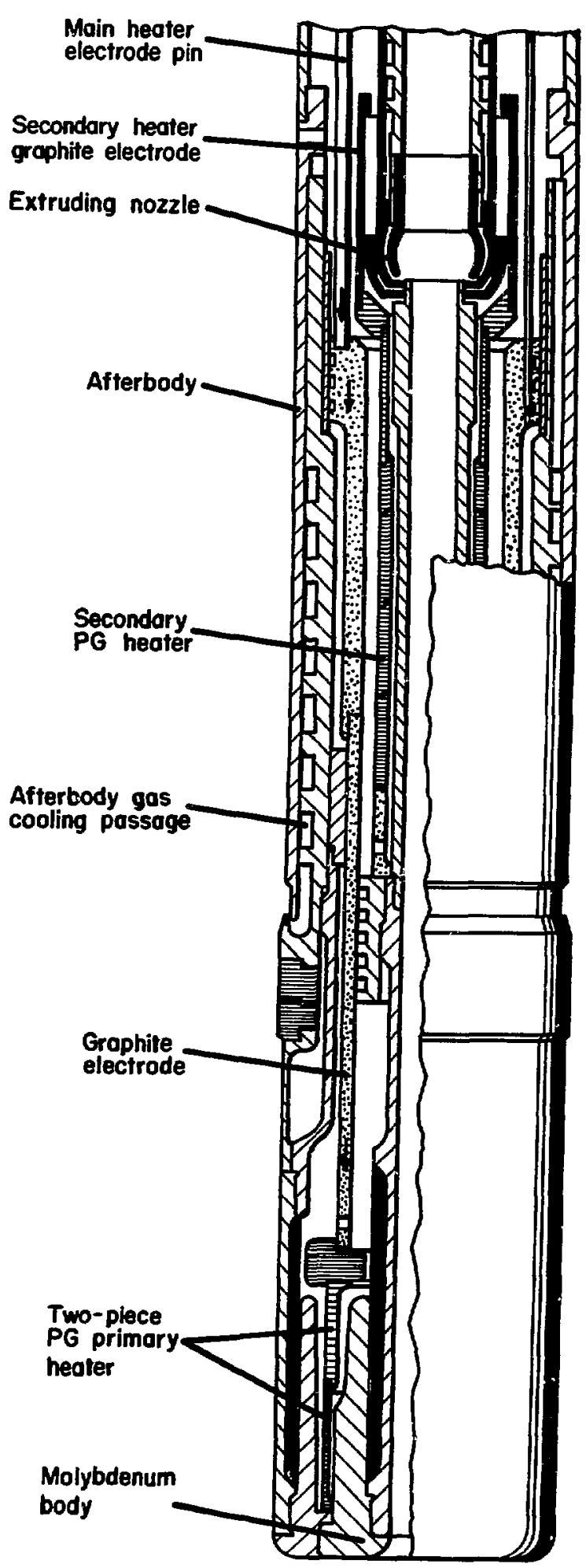

Fig. 28. Secondary-heater extruding penetrator. 
with a cylinarical heater 38 mu high by 90$\mathrm{mm}$ diameter, having a wall thickness of $1.6 \mathrm{~mm}$, operating at $750 \mathrm{~A}$ and $33 \mathrm{~V}$. Fig. 29 is a sketch of this penetrator.

\section{f. Summary of Experimental Heaters and Prototype Penetrators}

Table II summarizes the characteristics of the penetrator-heater systems described above. Some of these systems will be investigated in more detail, along with other concepts that may have advantages for specific applications. In particular, the relationship of current and voltage is important in field applications, where stem construction and powersupply characteristics are sensitive to the current reguirements of the penetrators. In general, heater operation at higher voltages and lower currents seems to be advantageous.

\section{SUPPORTING STUDIES AND EXPERIMENTS TO DEVELOP DESIGN DATA}

A. Materials Compatibility studies Materials compatibility studies have been concurrent with the design and testing of prototype penetrators. A report $^{12}$ has been issued and aiscusses the observed chemical reactions in penetrators fabricated from graphite, boron nitride, and molybden:m in terms of the thermodynamic stability of the pcssible reaction products. Another report ${ }^{8}$ discusses the carbon-molybdenum reactions and uses published diffusion data to predict temperature levels within the penetrator body.

A specific heater test was conducted in flowing helium. The assembly consisted of an outer molybdenum cylinder, an internally threaded boron-nitride insulator, and a graphite spiral heater, as shown in Fig. 30. This unit was cperated for $6 \mathrm{~h}$ at temperatures up to $2100 \mathrm{~K}$ at the heater surface and of $1900 \mathrm{~K}$ at the outer molybdenum surface. A heat flux of $0.4 \mathrm{MW} \cdot \mathrm{m}^{-2}$ was obtaineci. Although this test was encouraging, the difficulties of

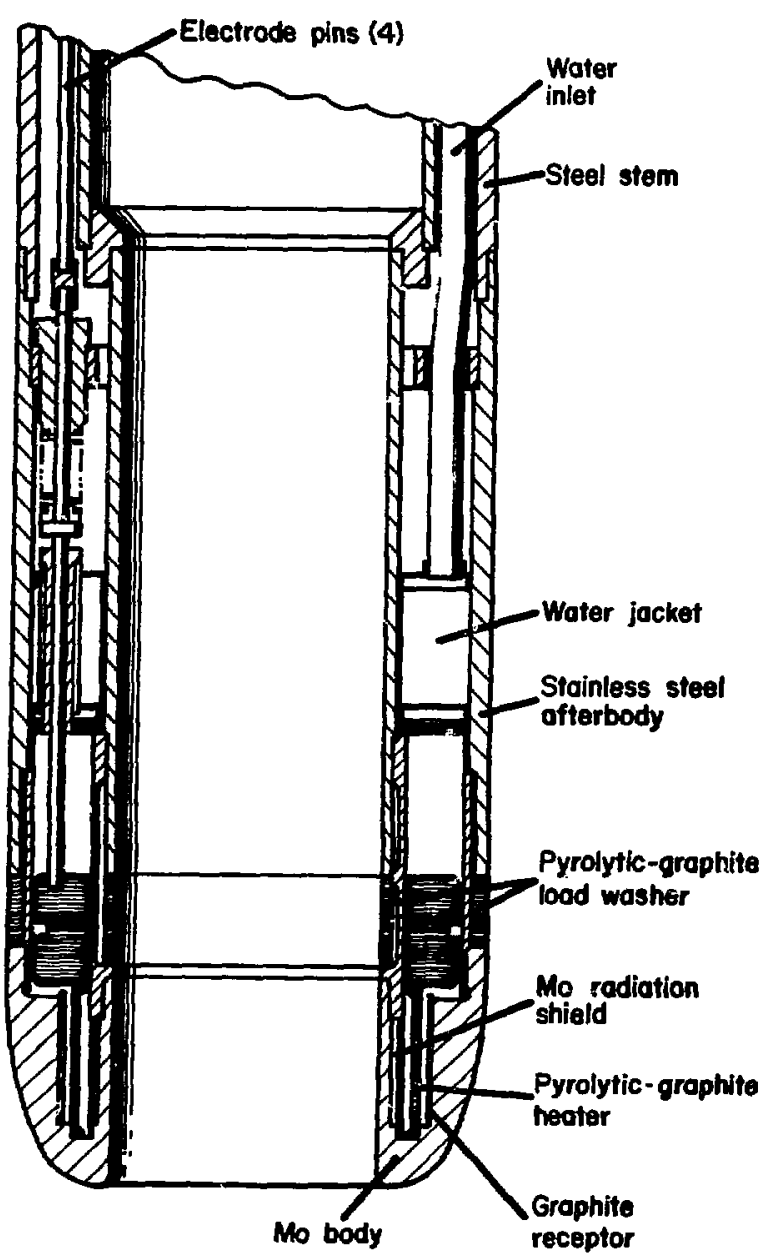

Fig. 29. Alluvium 114-mm-diam coring penetrator.

maintaining adequate contact between materials of such different thermal-expansion characteristics suggests that more testing would be needed before this system can be successfully incorporated in a long-lifetime penetrator.

\section{B. Thermal Emissivity Studies}

The use of radiant heaters to produce high heat fluxes requires that the radiating and recepting surfaces have relatively high thermal emissivities. Otherwise the heater temperature could increase to the point at which the materials could fail. A study of surface preparations of 
TABLE II

SUMEARY OF PENETRATOR-HEATER SYSTEY CHAHACTERISTICS

\begin{tabular}{|c|c|c|c|c|c|c|c|c|}
\hline \multirow[b]{2}{*}{ Plg. } & \multirow[b]{2}{*}{$\begin{array}{c}\text { Penetzator } \\
\text { Type } \\
\end{array}$} & \multirow[b]{2}{*}{$\begin{array}{c}\text { Heater } \\
\text { Type }\end{array}$} & \multirow[b]{2}{*}{ Materjals } & \multicolumn{4}{|c|}{$\begin{array}{c}\text { Houter Charackeristics at Operating } \\
\text { Temicrature }\end{array}$} & \multirow{2}{*}{$\begin{array}{l}\text { Nax heat Flux at } \\
\text { Heater Surface } \\
\mathrm{Mk}^{-\mathrm{m}^{-2}}\end{array}$} \\
\hline & & & & $\begin{array}{l}\text { Resistance } \\
\text { Ohmos n } \\
\end{array}$ & $\begin{array}{l}\text { Voltage } \\
\text { volts } \\
\end{array}$ & $\begin{array}{l}\text { Current } \\
\text { Amperes }\end{array}$ & $\mathrm{kw}$ & \\
\hline 1 & $\begin{array}{l}\text { 50-ran } \\
\text { Extruder }\end{array}$ & conduction & $\begin{array}{l}\text { Tungsten wire, } \\
\text { Bu, Eo }\end{array}$ & - & - & -- & -+ & -- \\
\hline 2 & $\begin{array}{l}\text { 50-min } \\
\text { Consolidavor }\end{array}$ & Conduction & Tungsten wire & 0.3 & 100 & 30 & 3.0 & 1.8 \\
\hline 6 & $\begin{array}{l}25-\mathrm{mm} \\
\text { Consolidator }\end{array}$ & $\begin{array}{l}\text { Directly } \\
\text { Heated }\end{array}$ & Tungston & 0.005 & 1 & 2000 & 2.0 & 0.4 \\
\hline 7 & $\begin{array}{l}\text { 50-man } \\
\text { Consolldator }\end{array}$ & $\begin{array}{l}\text { Direct/ } \\
\text { Conduetion }\end{array}$ & $\begin{array}{l}\text { Tungsten, } \\
\mathrm{Al}_{2} \mathrm{O}_{3} \text { : } \\
\text { Holybdenum }\end{array}$ & - & - & - & -- & - \\
\hline 8 & $\begin{array}{l}50 \text {-gim } \\
\text { Extruder }\end{array}$ & Conduction & $\begin{array}{l}\text { Tungs Len } \\
\text { BN, Hol ybdenum }\end{array}$ & $=$ & - & $\rightarrow$ & - & - \\
\hline 9 & $\begin{array}{l}\text { 50-ming } \\
\text { Consolidator }\end{array}$ & Conduction & $\begin{array}{l}\text { Graphite, } \\
\text { BN }\end{array}$ & -- & $-\infty$ & $\omega$ & - & - \\
\hline 12 & $\begin{array}{l}50 \rightarrow \text { grin } \\
\text { Congollidator }\end{array}$ & Conduction & $\begin{array}{l}\text { Graphite, } \\
\text { BN, No }\end{array}$ & 0.043 & 12 & 270 & 3.25 & 1.5 \\
\hline 23 & $\begin{array}{l}\text { 50-m } \\
\text { Extruder }\end{array}$ & $\begin{array}{l}\text { Direct Iy } \\
\text { Heated }\end{array}$ & Graphite & - & $-\infty$ & - & - & $=$ \\
\hline 14 & $\begin{array}{l}\text { 50-ura } \\
\text { Extruder }\end{array}$ & Conduction & $\begin{array}{l}\text { Graphite } \\
\text { BN, Ho }\end{array}$ & 0.044 & 9.8 & 220 & 2.2 & 0.7 \\
\hline $15^{(1)}$ & $\begin{array}{l}\text { 50-HH HOD-1 } \\
\text { Consolidator }\end{array}$ & Conduction & $\begin{array}{l}\text { Grapnite. } \\
\text { BN. No }\end{array}$ & 0.014 & 8.3 & 320 & 2.65 & 2.6 \\
\hline $15^{(2)}$ & $\begin{array}{l}\text { so-min MoD-2 } \\
\text { Consol idator }\end{array}$ & Conduction & $\begin{array}{l}\text { Graphite, BN, } \\
\text { TaC, No }\end{array}$ & 0.030 & 10 & 360 & 3.6 & 1.58 \\
\hline 16 & $\begin{array}{l}\text { 50-mor } \\
\text { Consoliajator }\end{array}$ & Radiation & $\begin{array}{l}\text { Graphite, } \\
\text { EN, tio }\end{array}$ & 2.03 & 102 & 36 & 3.67 & 1.5 \\
\hline 17 & $\begin{array}{l}\text { 50-man } \\
\text { Consol idator }\end{array}$ & $\begin{array}{l}\text { Radiation/ } \\
\text { Heat Pipe }\end{array}$ & $\begin{array}{l}\text { Graphite, } \\
\text { Ko, Li }\end{array}$ & 0.84 & 57 & 68 & 3.9 & 2,5 \\
\hline 18 & $\begin{array}{l}\text { S1-turn } \\
\text { Consol idator }\end{array}$ & Radiation & Graphite, No & 0.25 & 36 & 146 & 5.2 & 1.55 \\
\hline 21 & $\begin{array}{l}\text { 51-2un } \\
\text { Consol idator }\end{array}$ & Padiation & Graphite, wo & 0.45 & 45 & 100 & 4.5 & 0.58 \\
\hline 22 & $\begin{array}{l}75-\operatorname{mu} \\
\text { Consolidator }\end{array}$ & Radiation & Graphite, Yo & -- & - & - & - & - \\
\hline 23 & $\begin{array}{l}\text { 64-minder } \\
\text { Extruder }\end{array}$ & $\begin{array}{l}\text { Radiation } \\
\text { 3-paral lel } \\
\text { heaters }\end{array}$ & Graphite, Mo & 0.19 & 33 & 192 & 6.3 & 1.65 \\
\hline 24 & $\begin{array}{l}57-\mathrm{mm} \\
\text { corer }\end{array}$ & $\begin{array}{l}\text { Radiation } \\
\text { annular }\end{array}$ & Graphite & 0.023 & 5.4 & 240 & 1.3 & 0.3 \\
\hline 25 & $\begin{array}{l}\text { 57-grm } \\
\text { Extruder }\end{array}$ & $\begin{array}{l}\text { Rad:ation } \\
\text { annular }\end{array}$ & Graphite, to & 0.044 & 13.3 & 305 & 1.1 & 0.9 \\
\hline 26 & $\begin{array}{l}\text { S7-min } \\
\text { Extruder, } \\
\text { Stripping nozzl }\end{array}$ & $\begin{array}{l}\text { Radiation } \\
\text { annular } \\
\text { le }\end{array}$ & Graphite, Mo & 0.061 & 17 & 280 & 1.8 & 1.0 \\
\hline 28 & $\begin{array}{l}314-\mathrm{mm} \\
\text { Corer }\end{array}$ & $\begin{array}{l}\text { Radiation } \\
\text { annular }\end{array}$ & Graphite, to & 0.043 & 35 & 750 & 25 & $1.5^{\mathrm{b}}$ \\
\hline
\end{tabular}

molybdenum to increase the intrinsically low thermal emissivity was initiated. The results suggested that a thin graphite sleeve, as used in several penetrator designs, wa: the most reliable single means to provide this increase. However, because surface carbiding of molybdenum in contact with graphite poses a problem, some stable surface treatment would probably be the better design approach.

Experimental configurations are shown in Figs. 31 and 32. Cylinders with the desired surface treatment were self-heated by the passage of a direct current. Voltage probes in the central uniform temperature region permitted a calculation of input power for a known surface area. The true remperature of the surface was obtained optically by observing the interior of the cylinder. Surface temperatures were obtained similarly. A comparison of the interior temperature and apparent surface temperature produced values for spectral emissivities at $0.65 \mu \mathrm{m}$. Total emissivities were calculated from the electric power generated and the interior temperature. Calculations assumed that heat flows were radial only and that the temperature differences between the inside and outside surface of the thin-walled cylinde: were 


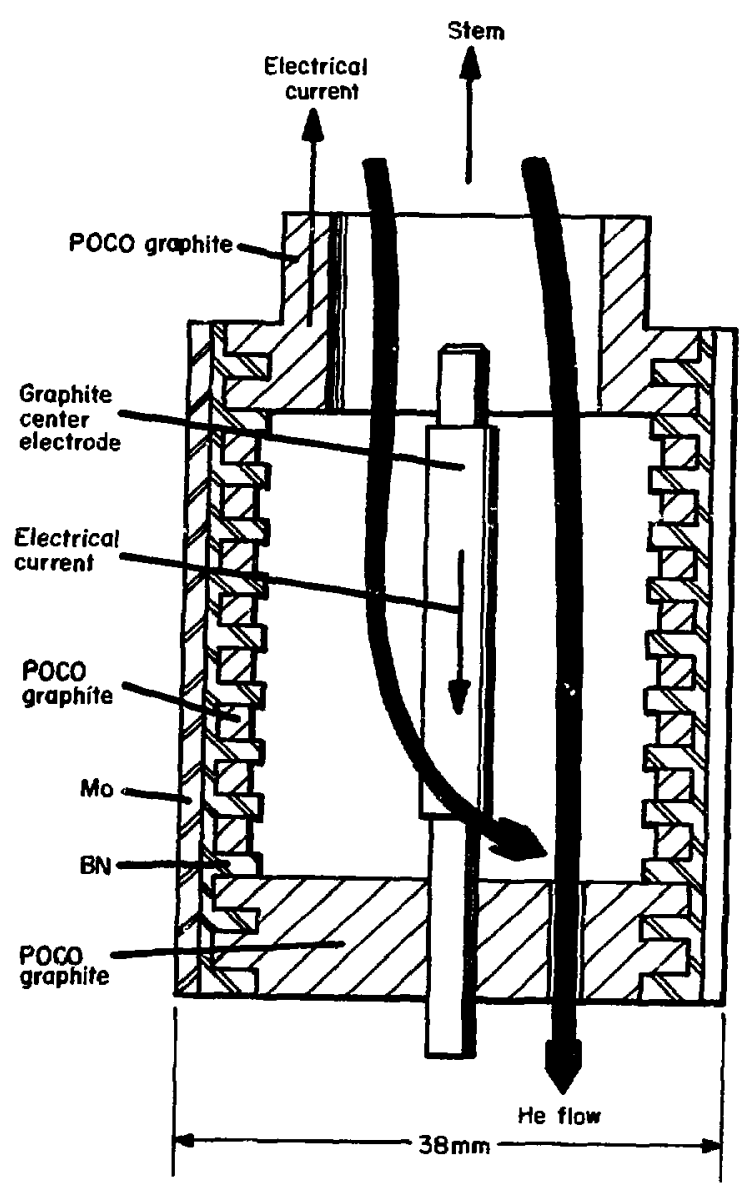

Fig. 30. Graphite spiral-heater test assembly.

negligible. The heated length was about $130 \mathrm{~mm}$ and the diameters were about $13 \mathrm{~mm}$.

The results indicated that for each surface treatment an initially higher emissivity was obtained than for a polished surface. A gradual reversion toward the intrinsically low vai:je occurred with time and increasing temperature. The most stable surface was obtained by coarse siliconcarbide grit-blasting of a finely threaded surface, then stabilizing this surface by gas-carburization with methane. These results are listed in Table IIT.

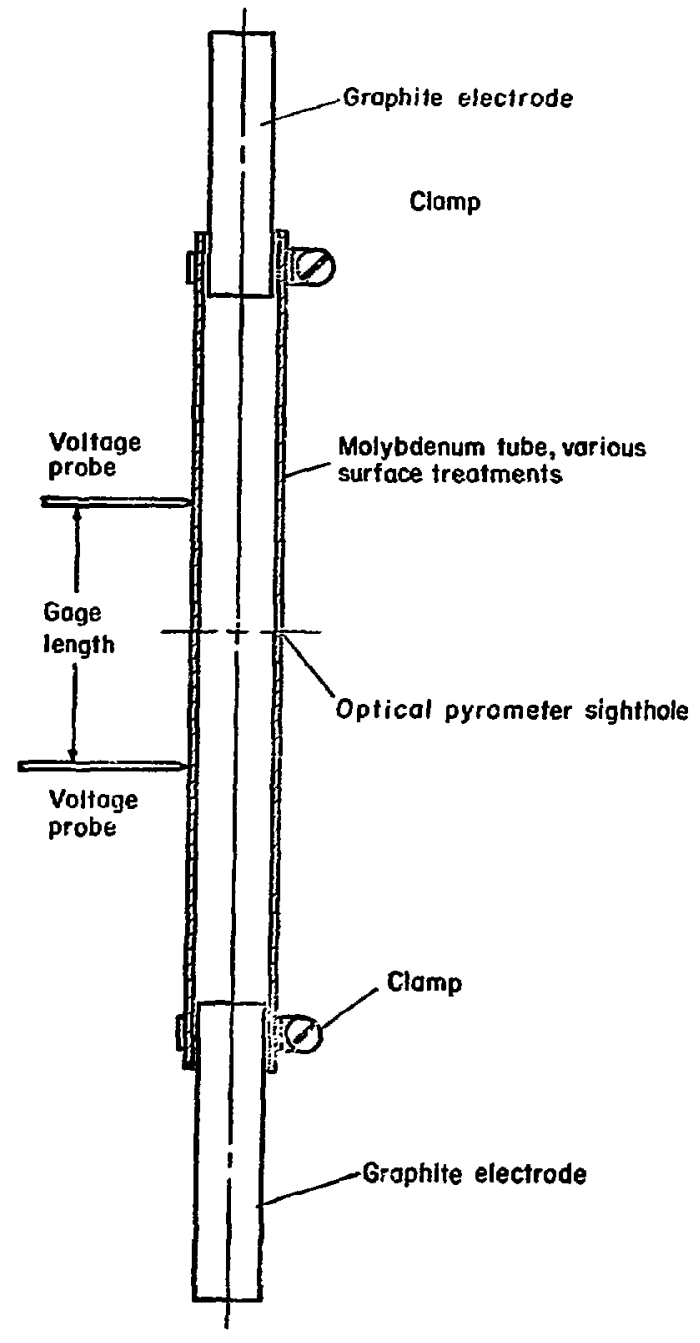

Fig. 31. Thermal-emissivity test assembly.

\section{c. Thermionic Emission Studies}

Persistent heater failures by internal arcing in several early penetrators led to a study of the thermionic emission of heater surfaces. It was assumed that sigrificant electron flow through gas gaps between hot surfaces of different potentials was the precursor to catastrophic failure by arcing. 'ihe experimental arrangement shown in Fig. 33 was prepared. A directly heated cylinder of suitable surface was placed in a vacuum envelope and a potential was impressed between this and another concentric cylinder. Guard rings rere 
TABLE III

TOTAL AND SPECTRAI EMISSIVITIES OF MOLYBDENUM SURFACES

\section{Conditions}

As-received condition; partially thermally etched during test thermal etching, sequential measurements at - 4-min intervals
Repolished surface to remove

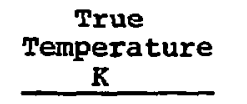

1530

1292

1311

1732

1735
Gage length lightly grit-blasted with 80-mesh SiC abrasive; sequential measurements at 20-min intervals.

Gage length heavily grit-blasted with 80-mesh SiC abrasive, electrochemically etched with NaOs; sequential measurements at about 130 -min intervals.

Repeat heating of previous specimen after $30 \mathrm{~min}$ of slow heating to measurement temperatures; sequential measurement at about 7 -min intervals.

Graphite-coated, grit-blasted surface (Aquadag-baked at $1100^{\circ} \mathrm{C}$ ): sequential measurement at 6-min intervals. About 58 of surface area lost the coating.

1157

1260

1520

1533

1527

1454

1339

1612

1445

1149

1321

1532

1545

1563

1119

60-DEG $V$-thread, 1.6 threads per millimeter

Game threaded sample, with "Number-54" S16. grit-blasted; methane atmosphere; pressure, 500 Torr.

Total
Emissivity

Emissivity at $0.65 \mu \mathrm{m}$

0.30

0.36

0.20

0.48

0.20

0.44

0.21

0.36

0.21

0.36

0.39

0.64

0.44

0.60

0.37

0.58

0.39

0.56

0.37

0.49

0.48

0.53
1193

1673

1603

1663

1833

1923

1943
0.26

0.28

0.25

0.50

0.48

0.48

0.73

0.63

0.70

0.76

0.75

0.78

0.73

0.78

0.70

0.78

0.43

0.56

0.41

0.53 


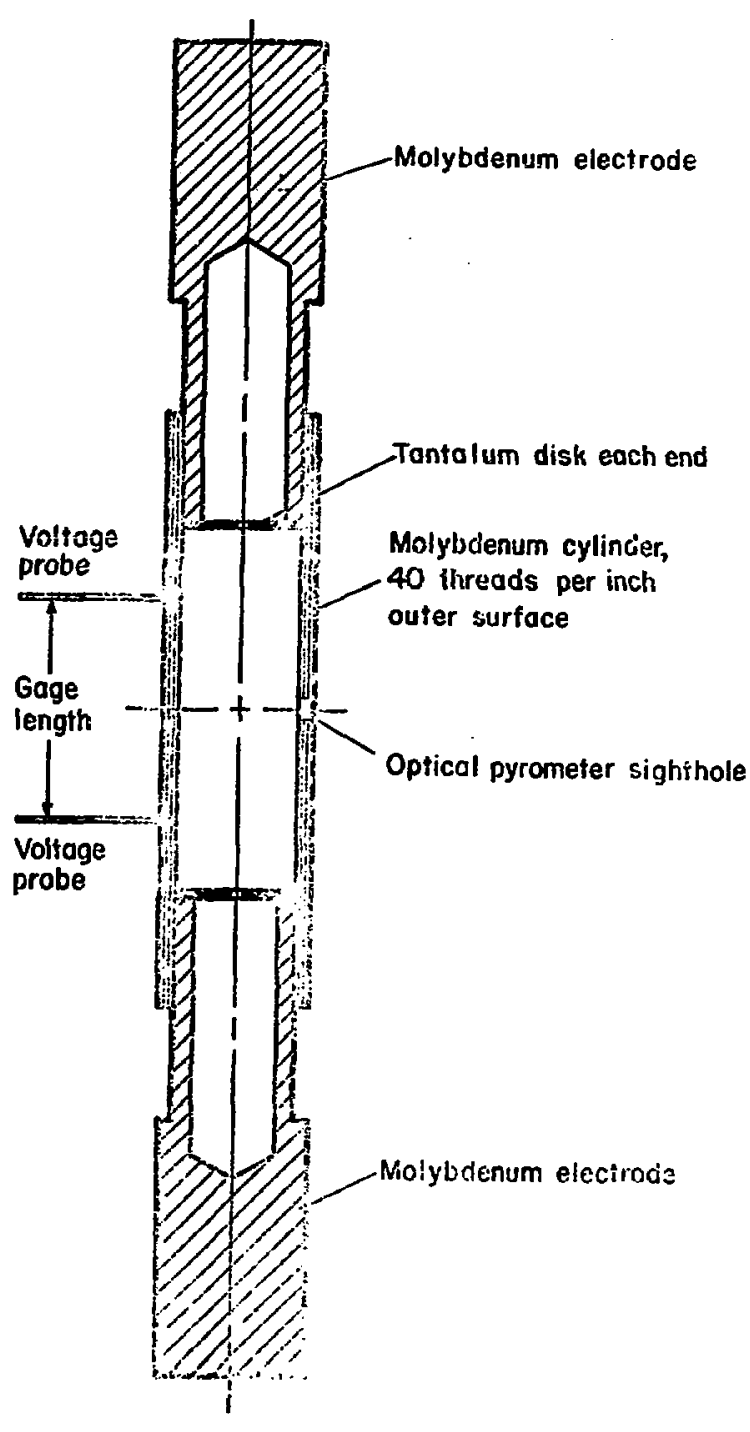

Fig. 32. Thermal-emissivity test assembly, second configuration.

provided at the same potential to prevent nonuniform field effects at the receptor cylinder ends. Temperatures were measured optically. The results are shown in Fig. 34 for the conditions of the central cylinder negative with respect to the receptor, and positive with respect to the receptor. Very small currents were obtained when the hotter central cylinder was positive, and significant currents were observed when the polarity was reversed. All penetrators

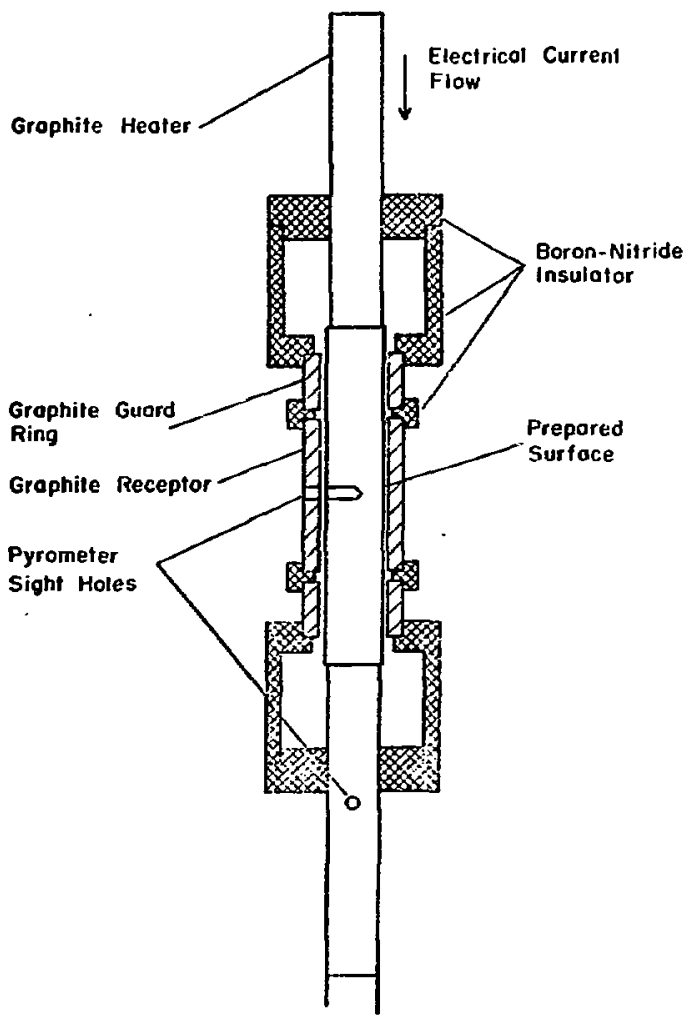

Fig. 33. Experimental assembly for electron emission studies.

were subsequently operated with the heater positive with respect to the heater cavity walls.

\section{Studies of the Electrical Resistiv- \\ The elcctrical resistivity of pyro-} lytic graphite in the direction perpendicular to the basal planes (the c-direction and the one of highest resistivity) has a strong negative temperature-dependence. This change in resistivity with temperature was observed in the operation of penetrators and provided an indication of the heater temperature during testing. Because it was difficult to sredict the effect of interfaces and matcrial variations of resistivity, an experiment was performed by using the stacked heatur disks of the consolidating penetrator, but in a vacuum 


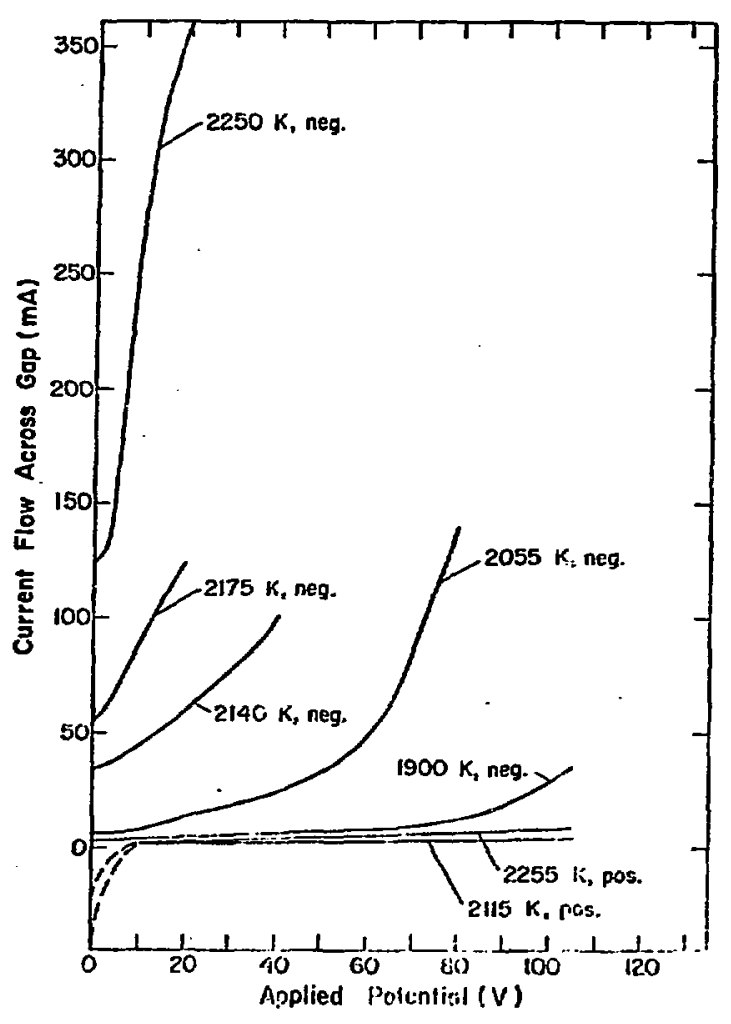

Fig. 34. Results of electron emission studies, with the hotter inner cylinder at indicated polarity.

envelope. Heating was accomplished by passing a direct currentthrough the stack via graphite spring-loaded electrodes. Potential leads were used to measure a voltage across a known gage length. Resistiv ity could then be calculated from the voltage, current, and dimensional measurements. The results shown in Fig. 35 for a stack of three and a stack of five disks were then used to predict heater temperatures in penetrator tests. Theoretical consideracions suggest that a minimum occurs in the resistivity curve, and that the temperature of this minimum varies with the perfection of the material. From these results, the minimum would be above $2700 \mathrm{~K}$.

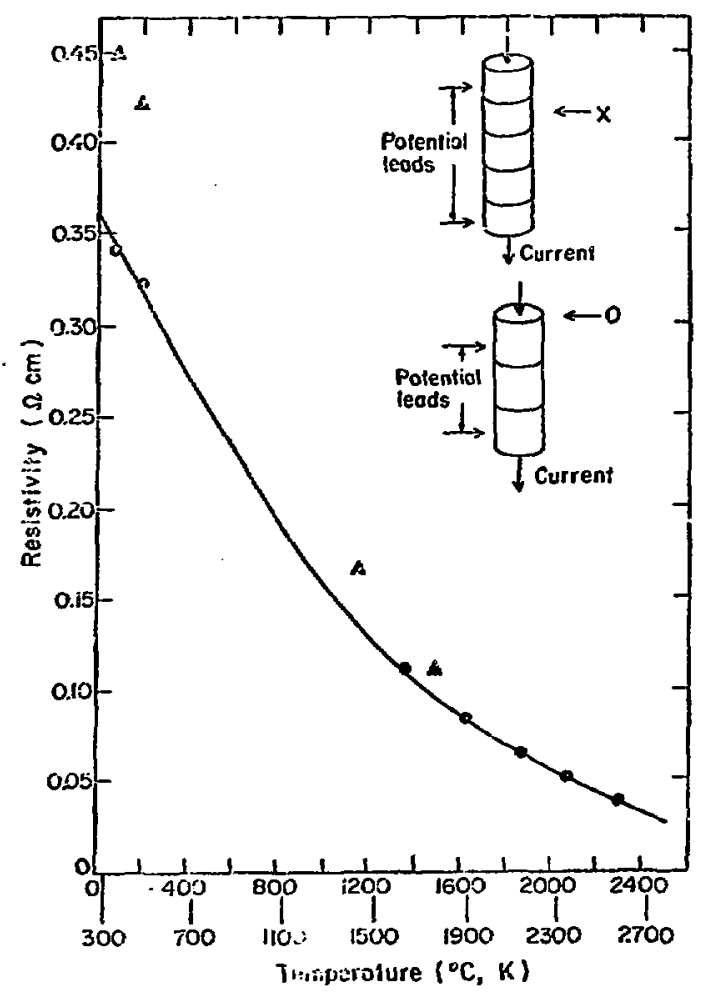

Fig. 35. Electrical characteristics of stacked pyrolytic-graphite disks.

\section{DESIGN STUDIES FOR OTHER TYPES OF ELECTRICAL HEATING}

A. Electron Beam Internal Heating

Supporting studies (see Section III), seem to indicate an upper limit of $\sim 100 \mathrm{~V}$ for the operation of radiant heaters. This voltage may also be a limit for conduction heaters although more study is needed in this respect. For deep-drilling, the power lost in the stem in transmitting the hundreds of amperes required for radiant heaters is a critical problem. The need for high currents could be alleviated, e.g., by electron-beam heating the penetrator body. The energy in the beam can be controlled over a wide range of voltages and currents. For example, a $10-\mathrm{kW}$ heat requirement could be satisfied with a device operating at $10 \mathrm{kV}$ and $1 \mathrm{~A}$ electron current. The stem design then focuses or 


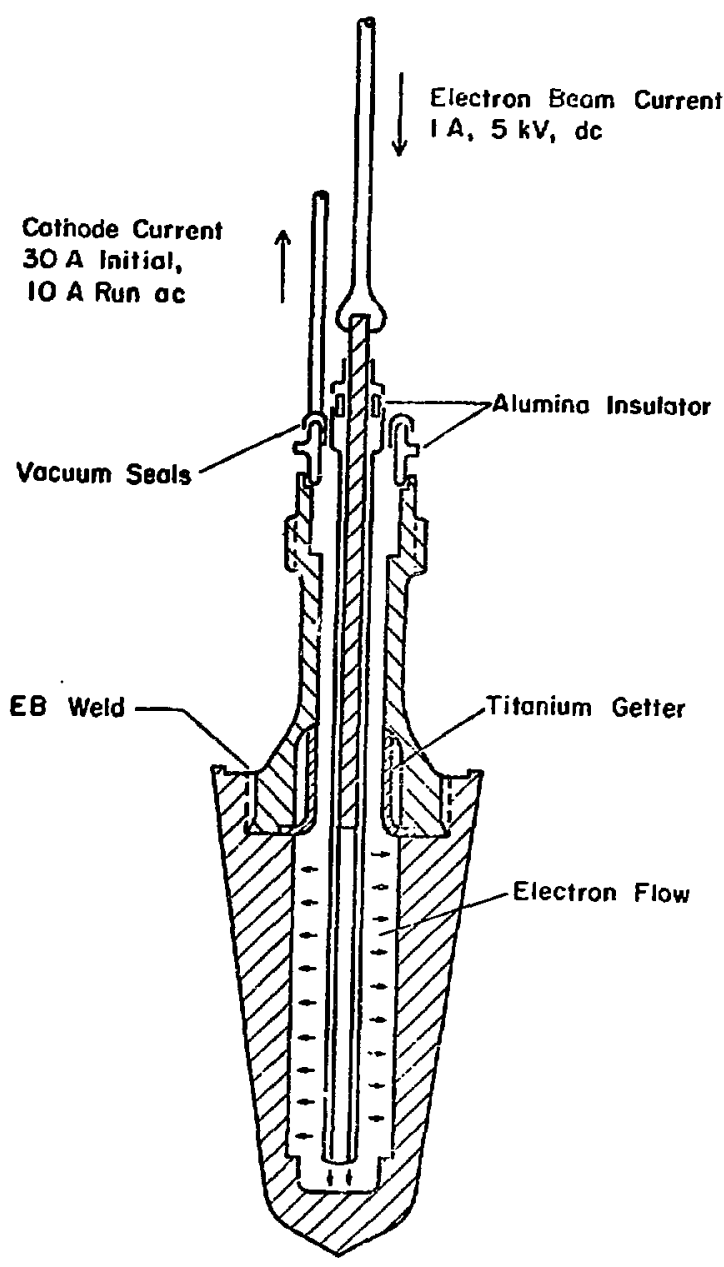

Fig. 36. Electron-beam-heated penetrator using a diode gun.

insulating for the high voltage, with conductors of relatively small cross section. It may be possible to construct electronbeam heaters in hermetically sealed configurations. The required high internal vacuum would be maintained by integral gettering materials. Two such design ideas are indicated in Figs. 36 and 37 . The first design employs a diode-gun structure with the cathode in the form of a concentric double tube. Initially, heat is supplied to raise the cathode to its operating temperature of $\sim 2500 \mathrm{~K}$ by direct

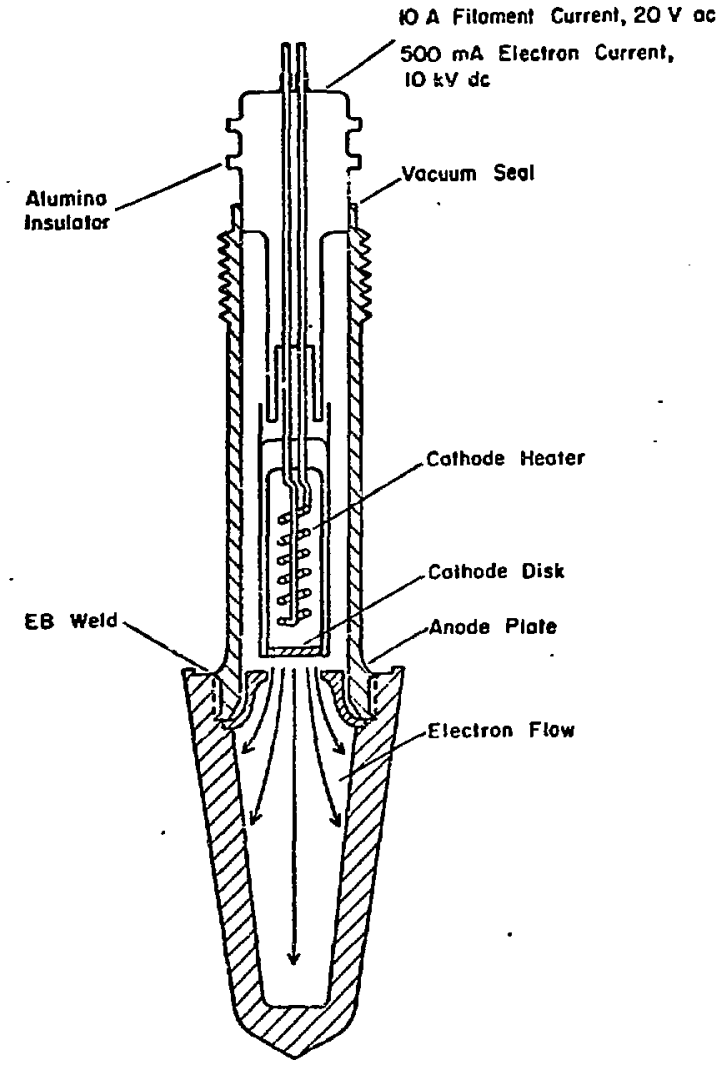

Fig. 37. Electron-beam-heated penetrator using a focused electron beam.

resistance heating. This would require $\sim 30 \mathrm{~A}$ at $20 \mathrm{~V}$. As the penetrator body reaches its operating temperature of - $1800 \mathrm{~K}$, much less current would be required to maintain cathode temperature. Because electron emission from the cathode is a strong function of temperature, the desired voitage-current relationship is simply maintained by controlling the heating current supplied to the cathode.

The second design uses an electron gun witi a suitable beam-shaping anode plate. The relatively small cathode area can be heated initially by a lower current than in the diode design, and this current would be further reduced as the penetrator body approaches its operating temperature. 


\section{B. Voltage-Current Conversion Schemes}

other schemes to reduce power loss

in the stem conductors have been considered. If alternating current is used, a down-hole transformer can couple a high-voltage, lowcurrent primary to a low-voltage, highcurrent secondary. Transmission of the high current could then be limited to distances less than one metre. Eddy-current and other alternating-current losses could be avoided by converting a low-current, high-voltage direct current to an alternating current in the region of the penetrator. Solid-state circuitry might be used to avoid problems of supplying filament current to vacuum-tube devices. The resulting alternating-current power could then be transferred to the penetrator body by resistance or inductive coupling. Because conversion efficiency should remain constant with increasing penetration depth, conversion losses would be less important at greater operating depths.

\section{CONCLUSION}

This report reviewed very briefly LASL's Subterrene rock-melting-penetrator development program from the viewpoint of heater design and performance. It thus represents a summary of ideas and concepts, and gives a brief description of harüware produced over the first few years of the program. This compilation will be of both historical and practical value to those interested in the subterrene program.

The pyrolytic-graphite radiation-heater system has proved to be reliable and to meet the needs of the present generation of procotype penetrators. Further development of this and other heater systems will benefit from sophisticated analytical tools that have been developed for the subterrene program.

\section{REFERENCES}

1. M. C. Smith, Ed., "A Preliminary Report of the Nuclear Subterrene," Los Alamos Scientific Laboratory report LA-4547 (1971)
2. D. E. Armstrong, J. S. Coleman, B. B. McInteer, R. M. Potter, and E. S. Robinson, "Rock Melting as a Drilling Technique," Los Alamos Scientific Laboratory report LA-3243 (1965).

3. J. W. Neudecker, "Design Description of Melting-Consolidating Prototype Subterrene Penetrators," Los Alamos Scientific Laboratory report LA-5212MS (1973).

4. J. W. Neudecker, A. J. Giger, and P. E. Armstrong, "Design and Development of Prototype Universal-Extruding Subterrene Penetrators," Los Alamos Scientific Laboratory report LA-5205-MS (1973).

5. R. G. Gido, "Description of Field Tests for Rock-Melting Penetration," Los Alamos Scientific Laboratory report LA-5213-MS (1973).

6. D. L. Sims, "Identification of Potential Applications for Rock-Melting Subterrenes," Los Alamos Scientific Laboratory report LA-5206-MS (1973).

7. R. G. Gido, "Internal Temperature Distribution of a Subterrene Rock-Melting Penetrator," Los Alamos Scientific Laboratory report LA-5135-MS (1973).

8. M. C. Krupka, "Internal Reaction Phenomena in Prototype Subterrene Radiant Heater Penetrators," Los Alamos Scientific Laboratory report LA-5094-MS (1972).

9. W. H. Smith and D. H. Leeds, "Pyrolytic Graphite," in Modern Materials, Advances in Development and Applications, Vol. 7, B. W. Gonser, Ed. (Academic Press, New York, 1970), Chap. 9, pp. 139-221.

10. Material Properties Data Book, Nerva Program, Vol.3, p. VII-A-13-12, Aerojet Nuclear Systems Co. report 2275 (1970).

11. Thermophysical Properties of High Temperature Solid Materials, Vol. 5 : Nonoxides and their Solutions and Mixtures, Including Miscellaneous Ceramis Materials, Y. S. Touloukian, Ed. (Macmillan Co., New York, 1967) p. 505.

12. M. C. Krupka, "Thermodynamic Stability Considerations in the Mo-BN-C System. Application to Prototype Subterrene Penetrators," Los Alamos Scientific Laboratory report IA-4959MS (1972).

13. R. G. Gido, "Subterrene Penetration Rate: Melting Power Relationship," Los Alamos Scientific Laboratory report LA-5204-MS (1973). 